\title{
14. ICHTHYOLITHS FROM SOME SOUTHEAST ATLANTIC SEDIMENTS, DSDP LEG 40
}

\author{
P.S. Doyle, M.J. Dunsworth, and W.R. Riedel, Scripps Institution of Oceanography, La Jolla, California
}

\section{INTRODUCTION}

Partly in order to increase our understanding of the stratigraphy of ichthyoliths, and partly to provide additional information on the ages of sparsely fossiliferous parts of the sediment column, we have examined microscopic fish skeletal debris from two drilling sites of Leg $40-$ Site $361 ; 35^{\circ} 03.97^{\prime} \mathrm{S}$, $15^{\circ} 26.91^{\prime} \mathrm{E}, 4549$ meters and Site $365 ; 11^{\circ} 39.10^{\prime} \mathrm{S}$, $11^{\circ} 53.72^{\prime} \mathrm{E}, 3018$ meters (Figure 1).

In some of the cores that we have examined from Site 361 , other microfossil groups have provided age assignments as follows:

Core 9 is upper Paleocene on the basis of calcareous nannofossils;

Core 10, Section 2, is lower Paleocene on the basis of calcareous nannofossils;

Cores 12-25 are Cretaceous on the basis of calcareous nannofossils;

Cores 13-16 are Maestrichtian to Campanian on the basis of palynomorphs;

Core 14, Section 2, is lower Maestrichtian on the basis of planktonic foraminifers.

We have no information based on other microfossil groups, on the ages of the cores that we have examined from Site 365, with the exception of a determination of the radiolarian Theocyrtis tuberosa Zone (early Oligocene) for the two samples from Core 7.

The occurrences of ichthyoliths in the two sites are shown in Tables 1 and 2. In the Descriptive Section are given references to the subtypes described previously, as well as descriptions of 18 new subtypes. The system of describing and naming the ichthyoliths (Doyle et al., 1974; Dunsworth et al., 1975; Ramsey et al., in press) has had to be somewhat modified and expanded to accommodate the new forms described here-these successive modifications have made the ichthyolith literature rather difficult to use, and therefore a comprehensive revision of the descriptive system incorporating all modifications is now being prepared.

Newly described forms are listed in numerical order in Table 3, with their colloquial names.

\section{RESULTS}

In the section at Site 361 , it is interesting to note that a substantial change in the ichthyolith assemblages occurs between Cores 9 and 10, which are dated as upper and lower Paleocene, respectively. This provides a lower stratigraphic limit for several forms which were previously known to extend down through the Eocene. In samples from Core 10, Section 6, and below, the ichthyoliths cannot provide as detailed an interpretation as have the other microfossil groups-all

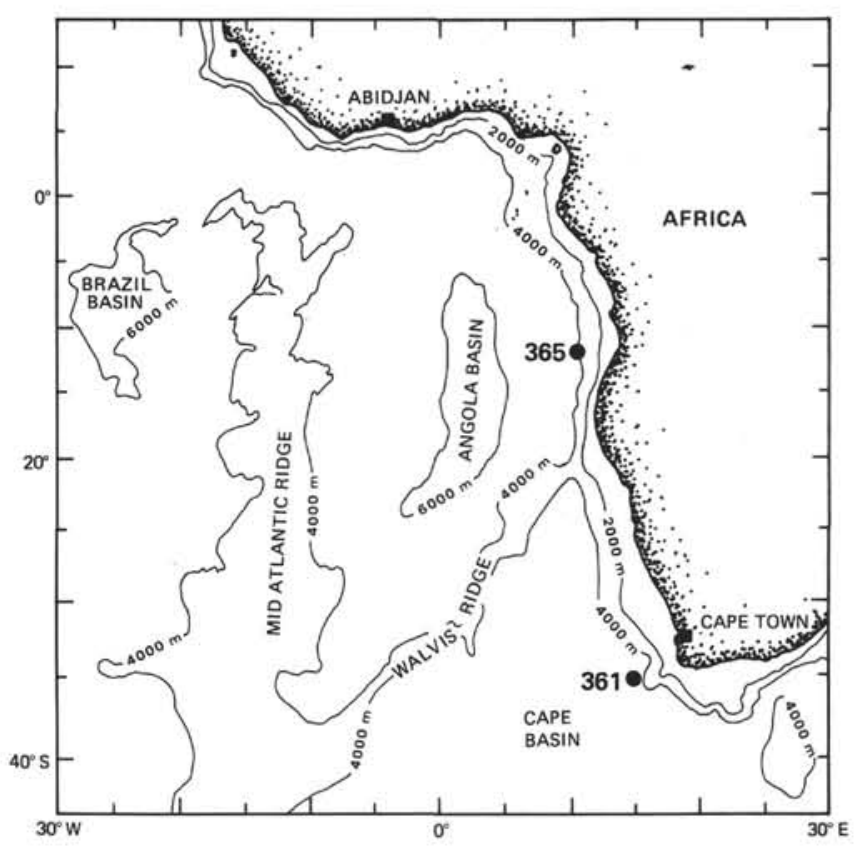

Figure 1. Location of DSDP Leg 40 Sites 361 and 365.

that can be said is that some of the ichthyoliths found in those assemblages have been recorded previously from the Cretaceous, and that there are rather marked changes between Sections 2 and 6 of Core 10, and between Cores 16 and 25. Many of the new forms occurring in this Cretaceous-Paleocene section have coherent ranges, and thus show promise of stratigraphic utility.

At Site 365, the ichthyolith assemblages of Cores 4 through 6 indicate early Miocene through late Oligocene, with the Oligocene-Miocene boundary possibly near the top of Core 6. This interpretation of the ichthyoliths is consistent with the early Oligocene age assignment for Core 7 , based on radiolarians. There appear to be some reworked, pre-Oligocene ichthyoliths in Cores 4-7.

\section{CHANGES TO THE DESCRIPTIVE SYSTEM}

Following are the changes to the descriptive system, necessary in order to accommodate the new forms defined.

1) Under $b$, add the character-state

b. 8 a prominent polygon, near the outline and approximately concentric with it

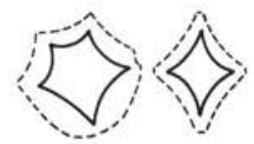

2) Modify the definition of transverse line (originally defined by Doyle et al., 1974, p. 827) to read as follows: 
TABLE 1

Distribution of Ichthyolith Subtypes in Site 361 (numbers of specimens found)

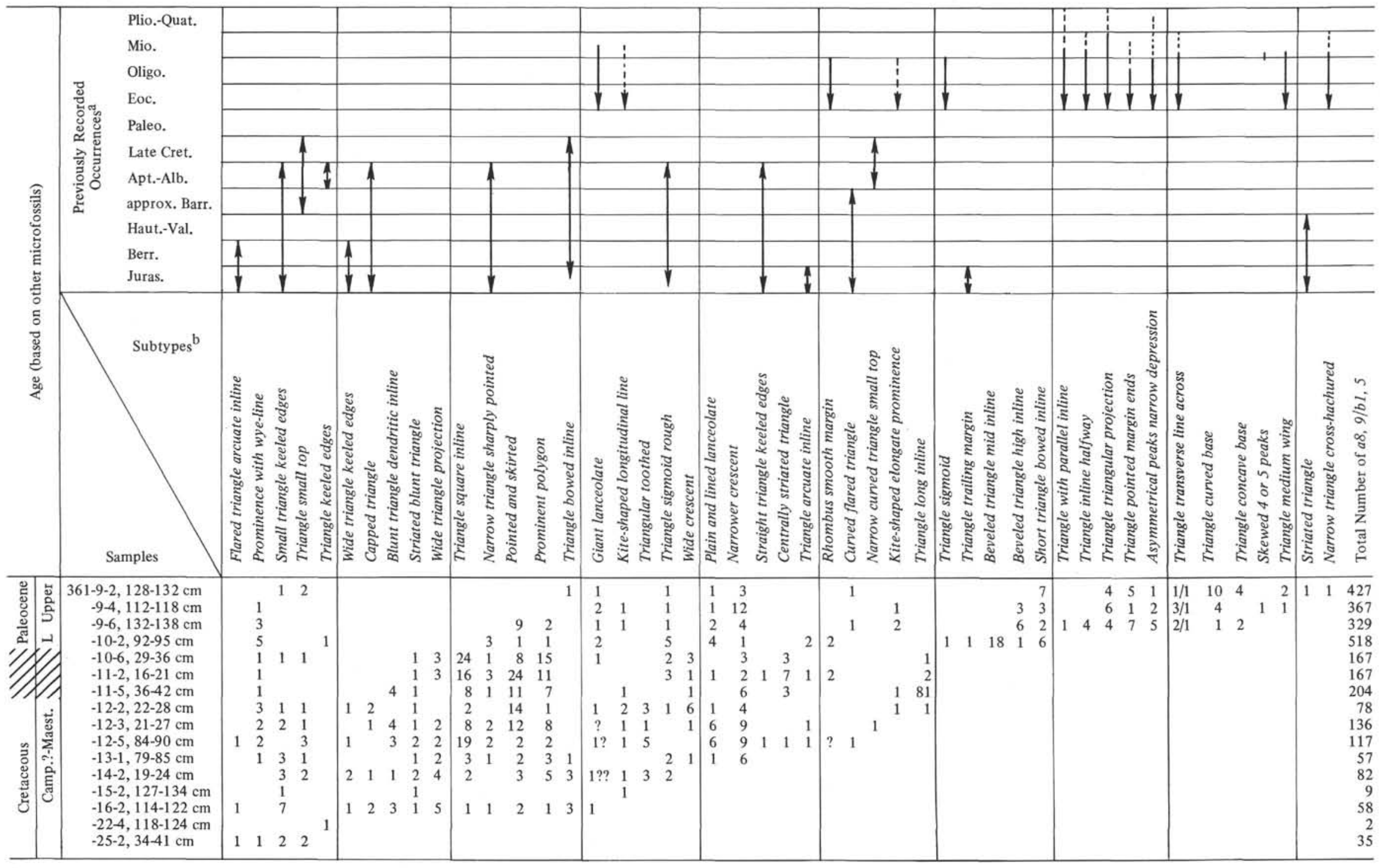

${ }^{a}$ The ranges of subtypes shown at the top of the table represent a synthesis of previously reported results. Arrows indicate possible extension of ranges.

${ }^{b}$ All ichthyolith subtypes described in Doyle et al. (1974), Dunsworth et al. (1975), Ramsey et al. (in press), as well as the new subtypes described herein were looked for. Only subtypes represented in the above samples are listed here.

In the column for Triangle Transverse line across are denoted "specimens representing upper part only/complete specimens". Question marks represent broken specimens. 
TABLE 2

Distribution of Ichthyolith Subtypes in Site 365 (numbers of specimens found)

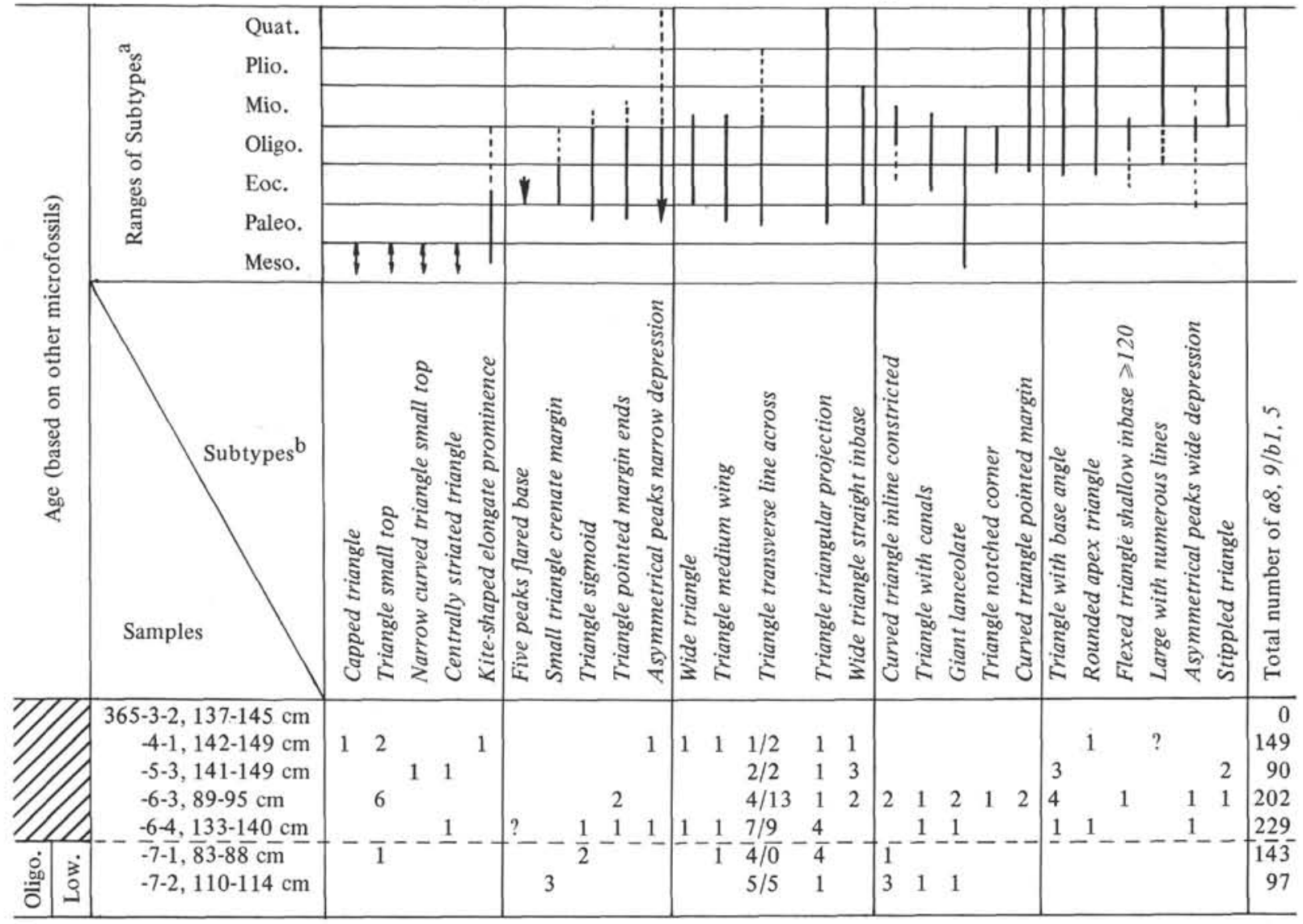

${ }^{\mathrm{a}}$ The ranges of subtypes shown at the top of the table represent a synthesis of previously reported results, as well as those from Site 361. Arrows indicate possible extension of ranges.

${ }^{b}$ All ichthyolith subtypes described in Doyle et al. (1974), Dunsworth et al. (1975), Ramsey et al. (in press), as well as subtypes described in this study were looked for, but only those subtypes represented in the above samples are listed here.

In the column for Triangle transverse line across are denoted "specimens representing upper part only/complete specimens". Question marks represent broken specimens.

"the nearest transverse line to the base, which extends at least from one side of the inline (when present) to the other and often further (but not to the base). In some specimens, the transverse line is above the top of the inline, but the term is not used for any line close to the margin in the upper part of the tooth and parallel to the outline."

3) Modify Type $a 3,4 / b /$ to Type $a 3,4 / b l, 2$ to admit forms with parallel or subparallel lines within the outline which, if they radiate, radiate from an edge or from a point on the margin

4) Under $a 3,4 / b l, 2$, modify the character-state $d .2$ to read "one line, not terminating in a Y-shaped fork at the end opposite the acute prominence"

5) Under $a 3,4 / b /, 2$, add the character-state

d.5 one line, terminating in a $\mathrm{Y}$-shaped fork at the end opposite the acute prominence

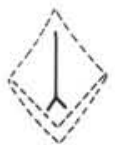

6) Under $a 3,4 / b /, 2$, modify the character-state $e .2$ to read "height greater than length of base, but less than twice length of base"

7) Under a3. 4/ bl, 2, modify the character-states g.l, g.3, g.5 and g. 7 by adding, after "long sides," "or the sides of the acute prominence"
8) Under $a .3,4 / b /, 2$, modify the character-states g.2, g.4. g.6 and g. 8 by adding, after "short sides," "or the sides other than those of the acute prominence"

9) Under a3, 4/ bl, 2, add the character

h. Degree of concavity of sides of acute prominence

1. straight or slightly concave

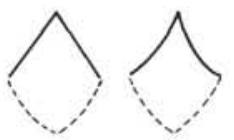

2. pronouncedly concave

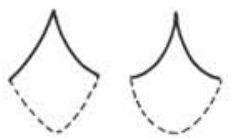

10) Modify the definition of acute prominence (originally defined by Doyle et al., 1974, p. 829) to read as follows:

"in a kite-shaped form, the triangle bounded by the two longer sides and the shorter diagonal; in a rhombus-shaped form, the more pointed triangle bounded by two similar sides and a diagonal; and in a lanceolate form, the pointed end"

11) Add Type $a 3,5 / b 8$, to describe forms polygonal, circular, or subcircular, with a prominent polygonal figure within the outline. 
Name-Descriptions of New Subtypes Described in This Study, Arranged in Numerical Order, With Equivalent Colloquial Names

\begin{tabular}{|c|c|c|c|c|c|c|c|c|c|c|c|c|c|c|c|c|c|c|c|c|c|c|}
\hline a & b & c & d & e & $\mathrm{f}$ & $\mathrm{g}$ & $\mathrm{h}$ & $\mathrm{i}$ & $\mathrm{j}$ & $k$ & 1 & $\mathrm{~m}$ & $\mathrm{n}$ & o & $\mathrm{p}$ & $q$ & $\mathrm{~s}$ & $s$ & $t$ & u & v & Names \\
\hline 3,4 & 1 & $1,2,3$ & $5,(4+5)$ & 2 & 2 & $1+8$ & 2 & & & & & & & & & & & & & & & Prominence with wye-line \\
\hline 3,4 & 1,2 & $2,3,4$ & $1,2,3$ & 1 & $2+3$ & $1+8$ & 1 & & & & & & & & & & & & & & & Pointed and skirted \\
\hline 3,5 & 8 & $5-8$ & $0.7-1.0$ & $60-100$ & & & & & & & & & & & & & & & & & & Prominent polygon \\
\hline 4 & 1,2 & 2 & $1,2,3$ & & $1,(2+3)$ & $1+2$ & 1 & & & & & & & & & & & & & & & Plain and lined lanceolate \\
\hline $\begin{array}{l}8 \\
9 \\
\end{array}$ & $\begin{array}{c}1,5 \\
1 \\
\end{array}$ & $\begin{array}{l}1 \\
1\end{array}$ & $\begin{array}{l}2 \\
1\end{array}$ & $\begin{array}{c}88-93 \\
1\end{array}$ & $\begin{array}{c}29-40 \\
10+(12,13)+14\end{array}$ & 1 & 4,5 & 2 & 2 & 11 & 0 & $1.1-1.6$ & $3,4,9$ & 1 & 1 & 1 & & & & & & Centrally striated triangle \\
\hline 8 & 1,5 & 1 & 3 & $80-115$ & $35-60$ & & & & & & & & & & & & & & & & & \\
\hline 9 & 1 & 1 & 1 & 1 & 4 & 1 & $2-5$ & 2.3 & 2,3 & 11 & 0 & 0 & $4,5,7,8$ & 1 & 3 & 1 & & & & & & Irlangle square inline \\
\hline 9 & 1 & 1 & 1 & 1 & 1 & 1 & $2,4,5$ & 2,6 & 2 & 8 & $0.2-0.3$ & $1.9-2.5$ & $6-8$ & 1,3 & 1,2 & 1 & & & & & & Triangle concave base \\
\hline 9 & 1 & I & 1 & 1 & $(1,4)+[1,(9+13+14)]$ & 1 & 4,5 & 3 & 3 & $5+8$ & 0 & $0.9-1.4$ & $7,8,9$ & 1 & 3 & 1 & & & & & & Narrower crescent \\
\hline 9 & 5 & 1 & 1 & 1 & 1 & 1 & 1 & $(1,5+4)[1,(11+15+16)]$ & 1 & 3 & 3 & 2,3 & 2,3 & 4,7 & $3+6$ & $0.4-0.9$ & $0.4-0.7$ & $1-1.9$ & 3 & 1 & 1 & Natrower cresectit \\
\hline 9 & 1 & 1 & 1 & 1 & 1 & 1 & 5 & 2,6 & 2,3 & 7,8 & $0.2-0.5$ & $2.5-4.9$ & 2 & 1 & 2 & 1 & & & & & & Triangle long inline \\
\hline 9 & 1 & $i$ & 1 & 1 & 1 & 1 & 5 & 2,3 & 3 & 3 & $0.4-0.6$ & $1.0-1.39$ & 2,6 & 1 & 3 & $i$ & & & & & & $\begin{array}{l}\text { Short triangle bowed } \\
\text { inline }\end{array}$ \\
\hline $\begin{array}{l}9 \\
8 \\
\end{array}$ & $\begin{array}{c}1 \\
1,5\end{array}$ & $\begin{array}{l}1 \\
1\end{array}$ & $\begin{array}{l}1 \\
3\end{array}$ & $\begin{array}{c}1 \\
80-115\end{array}$ & $\begin{array}{c}4 \\
35-60\end{array}$ & 1 & $2-5$ & 2,3 & 2,3 & 11 & 0 & 0 & $4,5,7,8$ & 1 & 3 & 1 & & & & & & Triangle square inline \\
\hline 9 & 1 & 1 & 1 & 1 & 4 & 1 & $2-5$ & 2,6 & 2,3 & $(7,8)+10$ & $0.25-0.5$ & $1.1-2.2$ & 7.9 & 1 & 3 & 1 & & & & & & Blunt triangle \\
\hline 9 & 5 & 1 & 1 & 1 & 1 & 1 & 1 & $4+5$ & 1 & 2,6 & 2,3 & 1 & 1 & 6,9 & $8+9$ & $0.2-0.4$ & $1.1-2.0$ & 0 & 3 & 1 & 1 & dendritic inline \\
\hline 9 & 1 & 1 & 1 & 1 & 4 & 1 & 4,5 & 3,5 & 3,5 & $5+8$ & $0.2-0.4$ & $0.4-0.8$ & 9 & 1 & 3 & 1 & & & & & & Wide crescent \\
\hline 9 & 1 & 1 & 1 & 1 & 4 & 1 & 5 & 3,2 & 2,3 & 3,7 & $0.5-0.7$ & $1.5-2.3$ & 6,7 & 1 & 1 & 1 & & & & & & \\
\hline 9 & 5 & 1 & 1 & 1 & 1 & 1 & 2 & $4+(1,6)$ & 1 & 2,3 & 2.3 & 2 & 2 & 4 & 4,8 & $0.5-0.7$ & $1.5-2.3$ & 0 & 1 & 1 & 1 & Triangle curved base \\
\hline 9 & 1 & 1 & 1 & 1 & $9+(12,13)+14$ & 1 & 4,5 & 3.2 & 2,3 & 11 & 0 & $0.9-1.4$ & $3,4,9$ & 1 & 3 & 1 & & & & & & Striated blunt triangle \\
\hline $\begin{array}{l}9 \\
8\end{array}$ & $\begin{array}{c}1 \\
1,5\end{array}$ & $\begin{array}{l}1 \\
1\end{array}$ & $\begin{array}{l}1 \\
2\end{array}$ & $\begin{array}{c}1 \\
88-93\end{array}$ & $\begin{array}{c}10+(12,13)+14 \\
29-40\end{array}$ & 1 & 4,5 & 2 & 2 & 11 & 0 & $1.1-1.6$ & $3,4,9$ & 1 & 1 & 1 & & & & & & Centrally striated triangle \\
\hline 9 & 1 & 13 & 13 & 1 & $1,(10+12+14)$ & 1 & 5 & 2 & 2,3 & 3,8 & $0.4-0.6$ & $1.2-1.6$ & 2 & 1 & 1 & 1 & & & & & & $\begin{array}{l}\text { Beveled triangle mid } \\
\text { inline }\end{array}$ \\
\hline 9 & 1 & 13 & 13 & 1 & 1 & 1 & 5 & 2 & 2 & 8 & $0.1-0.3$ & $1.7-2.1$ & 2 & 1 & 1 & 1 & & & & & & $\begin{array}{l}\text { Beveled triangle high } \\
\text { inline }\end{array}$ \\
\hline 9 & 5 & 1 & 1 & 1 & 1 & 1 & 1 & $1,5+4+[1,(11+15+16)]$ & 1 & 3 & 3 & 2,3 & 2,3 & 4,7 & $3+6$ & $0.4-0.9$ & $0.4-0.7$ & $1-1.9$ & 3 & 1 & 1 & Narrower crescent \\
\hline 9 & 1 & 1 & 1 & 1 & $(1,4)+[1,(9+13+14)]$ & 1 & 4,5 & 3 & 3 & $5+8$ & 0 & $0.9-1.4$ & $7,8,9$ & 1 & 3 & 1 & & & & & & \\
\hline $\begin{array}{l}9 \\
9 \\
\end{array}$ & $\begin{array}{l}5 \\
1 \\
\end{array}$ & $\begin{array}{l}1 \\
1\end{array}$ & $\begin{array}{l}1 \\
1\end{array}$ & $\begin{array}{l}1 \\
1\end{array}$ & $\begin{array}{r}1 \\
4 \\
\end{array}$ & $\begin{array}{l}1 \\
1\end{array}$ & $\begin{array}{r}1 \\
2-5\end{array}$ & $\begin{array}{l}4+5 \\
2,6\end{array}$ & $\begin{array}{c}1 \\
2,3\end{array}$ & $\begin{array}{c}2,6 \\
(7,8)+10\end{array}$ & \begin{tabular}{|l|}
2,3 \\
$0.25-0.5$
\end{tabular} & $\begin{array}{c}1 \\
1.1-2.2\end{array}$ & $\begin{array}{c}1 \\
7-9\end{array}$ & $\begin{array}{r}6,9 \\
1\end{array}$ & $\begin{array}{c}8+9 \\
3\end{array}$ & $\begin{array}{c}0.2-0.4 \\
1\end{array}$ & $1.1-2.0$ & 0 & 3 & 1 & 1 & $\begin{array}{l}\text { Blunt triangle } \\
\text { dendritic inline }\end{array}$ \\
\hline 9 & 5 & 1 & 1 & 1 & 1 & $i$ & 2 & $4+(1,6)$ & 1 & 2,3 & 2,3 & 2 & 2 & 4 & 4,8 & $0.5-0.7$ & $1.5-2.3$ & 0 & 1 & 1 & 1 & Triangle curved base \\
\hline 9 & 1 & 1 & 1 & 1 & 4 & 1 & 5 & 2,3 & 2,3 & 3.7 & $(0.5-0.7)$ & $1.5-2.3$ & 6,7 & 1 & 1 & 1 & & & & & & Triangle curved base \\
\hline 9 & 5 & 4 & 1 & 1 & 1 & 1 & 1 & 1 & 3 & 2 & 2 & 2 & 2,3 & 10 & 2,6 & 0 & $0.7-0.9$ & $1-3.0$ & 2 & 1 & 1 & Wide triangle projection \\
\hline 9 & 5 & 1 & 1 & 3 & 1 & 1 & 1 & 1 & 3 & 2 & 2 & 2 & 2,3 & 2,4 & 2 & 0 & $0.7-0.9$ & $1-3.0$ & 2 & 1 & 1 & Wide trangle projection \\
\hline 9 & 6 & $2-5$ & 2 & 1 & & & & & & & & & & & & & & & & & & Triangular toothed \\
\hline
\end{tabular}


c. Number of sides to the polygon

Number, not encoded

d. Regularity of prominent internal polygon

Ratio of length of shortest side to length of longest side

Range if numbers, not encoded

e. Size

Maximum dimension of the figures enclosed by the midpoints of the sides of the prominent internal polygon

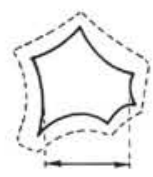

Range in $\mu \mathrm{m}$, not encoded

12) Under $a 9 / b /$, change $f$ and its character-states to read as follows:

f. Features between inline and outline (or, if inline not present, within outline)

1. as previously

2. no longer used (Dunsworth et al., 1975)

$3-5$. as previously

6-8. no longer used, herein

9. striations originating from more than the central half of length of inline (or, if inline not present, more than dentral half of length of base)

10. striations originating from the central half or less of length of inline (or, if inline not present, the central half or less of length of base)

11. striations restricted to lower half of area within outline
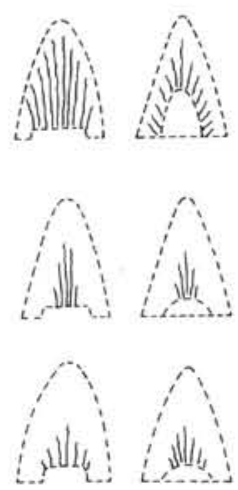

12. striations extending into upper half of outline, but not into the upper quarter

13. striations extending into upper quarter of outline

14. majority of striations departing less than $45^{\circ}$ from longitudinal axis

15. majority of striations departing more than $45^{\circ}$ from longitudinal axis
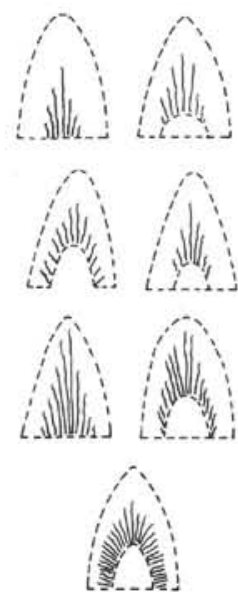

13) Under $a 9 / b /$, modify the character $n$ to read "Character of base within inline, or, if inline not present, of base itself"

14) Under $a 9 / b /$, add the character-state

k.10 apical part of inline dendritically branched
15) Under $a 9|b|$ add the character-state

k. 11 its apex not pointed, nor arcuate, but almost straight, transverse to the axis of the tooth

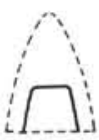

16) Under $a 9 / b 5$, character $i$, we no longer use the character-states $8-10$, but add the following states:

11. striations originating from more than the central half of length of inline (or, if inline not present, that of the transverse line)

12. striations originating from the central half or less of length of inline (or, if inline not present, that of the transverse line)

13. defined similarly to $a 9 / b l / f l l$

14. defined similarly to $a 9 / b l / f / 2$

15. defined similarly to $a 9 / b l / f l 3$

16. defined similarly to $a 9 / b / / f / 4$

17. defined similarly to $a 9 / b l / f l 5$

17) Under $a 9 / b 5$, add the character-state

o.10 flexed line terminating at margins at different levels

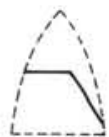

18) Under $a 9 / b 5$, add the character-state

p. 9 apical part of inline dendritically branched

\section{DESCRIPTIVE SECTION}

Here are given references to forms previously described, and descriptions of 18 new forms.

subtype a2 / b2 / c4, 5 / d1 / e2 / f2 / g1 / h2 / i1 / j2 / Skewed four or five peaks) Doyle et al., 1974, p. 844, pl. 1A, fig. 4; pl. 2B, fig. 4, 5.

subtype a2 / b2 / c5 / d3 / e1 / f1 / g1 / h4 / i1 / j1, 2 (Five peaks flared base) Doyle et al., 1974, p. 844, pl. 2B, fig. 6-8.

subtype a3, 4 / b1 / c1, 2, 3 / d5, (4+5) / e2 / f / g1 +8 / h2 Doyle et al., new subtype.

\section{Prominence with wye-line}

(Plate 1, Figures 1-4)

Characters: Lanceolate to kite-shaped forms. Acute prominence with sides pronouncedly concave, its height greater than length of base, but less than twice the length, and with a narrow differentiated area having a smooth and continuous margin. Sides other than those of the acute prominence may be irregularly undulating or broken. A longitudinal line terminating in a $\mathrm{Y}$ is present, and in many specimens a marginal series of lines sometimes forming an irregular network. Overall length $200-700 \mu \mathrm{m}$, width $150-450 \mu \mathrm{m}$. 361 .

Occurrence: In Cretaceous to late Paleocene sediments at Site

subtype a3, 4 / b1, 2 / c2, 3, 4 / d1, 2, 3 / e1 / f2 +3 / g1 +8 / h1 Doyle et al., new subtype.

\section{Pointed and skirted \\ (Plate 1, Figures 8-11)}

Characters: Lanceolate, kite-shaped or rhombus-shaped forms with a short acute prominence, its height equal to or less than length of base. Narrow differentiated area present on all sides; the margins of the sides of the acute prominence smooth and continuous, the other margins broken. Up to three or more subparallel lines may be present on main body. Overall length $200-450 \mu \mathrm{m}$, width $130-400 \mu \mathrm{m}$.

Occurrence: In late (?) Cretaceous to late Paleocene sediments at Site 361 . 
subtype $\mathbf{3} 3$ / b1 / c3 / d2 / e2 / $\mathbf{2}+3$ / g1 +2 (Kite-shaped longitudinal line) Doyle et al., 1974, p. 844, pl. 2C, fig. 1, 2.

subtype a3 / b1 / c3 / d3, 4 / e4 / 12 / g1 +8 (Kite-shaped elongate prominence) Doyle et al., 1974, p. 844, pl. 2C, fig. 3-6.

subtype a3 / b1 / c4 / d1, 3, 4 / e0 / f1, (2+3) / g1+2 (Rhombus smooth margin) Doyle et al., 1974, p. 844, pl. 2D, fig. 1-3.

subtype a3, 5 / b8 / c5, 6, 7, 8 / d0.70-1.0 /e60-100 Doyle et al., new subtype.

Prominent polygon

(Plate 1, Figures 5-7)

Characters: Small polygonal to subcircular forms (maximum dimension of the figure enclosed by the mid-points of the concave sides of the prominent internal polygon $60-100 \mu \mathrm{m}$ ), with a prominent, rather regular pentagon or hexagon near the outline and approximately concentric with it.

Remarks: This form was recorded from Aptian-Albian and Tithonian sediments in Italy by Ramsey et al. (in press, pl. 4, fig. 8, 9).

Occurrence: In late(?) Cretaceous to late Paleocene sediments at Site 361 .

subtype a4 / b1 / cl / d3 / e0 / $\mathbf{2}+3$ / g1 +2 (Giant lanceolate) Doyle et al., 1974, p. 844, pl. 2E, fig. 1-7.

subtype a4 / b1, 2 / c2 / d1, 2, 3 / e2 / f1, (2+3) / g1 + 2 / h1 Doyle et al., new subtype.

Plain and lined lanceolate

(Plate 1, Figures 12-15)

Characters: Lanceolate $(100-500 \mu \mathrm{m})$, with sides of acute prominence straight or slightly concave. A single line or several subparallel lines are present on some specimens. The margin is smooth and continuous, and a narrow differentiated area may be present.

Remarks: This subtype is defined to replace, and include a slightly wider range of forms than, $a 4 / b 1 / c 2 / d l / e 0 / f 1,(2+3) /$ $\mathrm{gl}+2$ (Plain lanceolate) of Doyle et al. (1974, p. 844, pl. 2F, fig. 1-4)

Occurrence: In late (?) Cretaceous to late Paleocene sediments at Site 361 , and previously recorded in early and middle Eocene (Doyle et al., 1974). There seems to be a tendency for specimens from older assemblages to be smaller.

subtype a5,6 / b3 / c2 / d1, 2 / e1 (Large with numerous lines) Doyle et al., 1974, p. 845 , pl. 1B, fig. 10-12; pl. 2F, fig. 8, 9.

subtype a 7 / b6 / c1 (Asymmetrical peak wide depression) Doyle et al., 1974 , p. 845 , pl. $1 \mathrm{D}$, fig. 9 , 10; pl. $2 \mathrm{G}$, fig. 9 .

subtype a7 / b6 /c3 (Asymmetrical peaks narrow depression) Doyle et al., 1974, p. 845 , pl. 1E, fig. 1, 2; pl. 2H, fig. 1-4.

subtype a8 / b1, 5 / c1 / d2, 3 / e $\geq 120$ / f $\leq 25$ (Flexed triangle shallow inbase $\geq 120$ ) Dunsworth et al., 1975 , p. 857 , pl. 1, fig. 4,5 .

subtype a9 / b1 / c1 / d1 / e1 / f1 / g1 / h1, 2, 3 / i2, 3 / j2, 3, / k2 / 10.25-0.45 / m1-1.5 / n4, 5 / o1 / p3 (Wide triangle straight inbase) Doyle et al., 1974, p. 846, pl. IF, fig. 7-9; pl. 2I, fig. 5-8.

subtype a9 / b1 / c1 / d1 / e1 / f1, 4 / g1 / h1 / 12 / j2 / k7 / 10.5-0.7 / m2.5-3.5 / n2 / o1 / p1, 2 (Triangle with parallel inline) Doyle et al., 1974 , p. 846 , pl. $1 \mathrm{H}$, fig. 4 , 5; pl. $2 \mathrm{~K}$, fig. 9-12.

subtype a9 / b1 / c1 / d1 / e1 / f1 / g1 / h2, 4, 5 / i2, 6 / j2 / k8 / 10.2 0.3 / m1.9-2.5 / n6, 7, 8 / o1, 3 / p1, 2 / q1 Doyle et al., new subtype.

Triangle concave base

(Plate 1, Figures 16, 17)

Characters: Moderately narrow triangle (length to width ratios 1.9-2.5). Inline usually parallel to the straight or slightly concave margins, its base curved, and its apex relatively close to apex of outline. Overall length $290-700 \mu \mathrm{m}$, width $130-300 \mu \mathrm{m}$.
Remarks: This subtype occurs in assemblages at least as young as early Eocene (DSDP $310-11-3,75-80 \mathrm{~cm}$ ).

Occurrence: In late Paleocene sediments at Site 361, and has been observed in early Eocene samples.

subtype a9 / b1 / c1 / d1 / e1 / f1, 8 / g1 / h3, 4, 5 / i2, 6 / j2, 3 / k9 /

10 / m4.3-5.3 / n9 / o1 / p2 / q1 (Narrow triangle sharply pointed) Ramsey et al., in press, pl. 2, fig. 3-5.

subtype a9 / b1 / c1 / d1 / e1 / f1 / g1 / h3, 4, 5 / i3 / j3 / k8 / $10.2-0.8$ / $\mathbf{m}<1$ / n4-8 / o1 / p3 (Wide triangle) Dunsworth et al., 1975, p. 857 , pl. 1 , fig. 17,18 .

subtype a9 / b1 / c1 / d1 / e1 / f1 / g1 / h5 / i2, 6 / j2, 3 / k7, 8 / $10.2-$ 0.5 / m2.5-4.9 / n2 / o1 / p2 / q1 Doyle et al., new subtype.

\section{Triangle long inline}

(Plate 2, Figures 1-3)

Characters: Very narrow triangle (range of length to width ratios 2.5-4.9). Inline approximately parallel to margins of outline, though much narrower, and extending almost to the top of the outline. Overall length, 200-600 $\mu \mathrm{m}$, width $60-110 \mu \mathrm{m}$.

Occurrence: In probably Maestrichtian sediments at Site 361 .

subtype a9 / b1 / c1 / d1 / e1 / f1, 4 / g1 / h5 / 22 / j2 / k3, 9 / $10.4-0.6$ / m1.4-2.8 / n2, 6 / o1 / p1, 3 / q4 (Triangle bowed inline) Ramsey et al., in press, pl. 3 , fig. 6-10.

subtype a9 / b1 / c1 / d1 / e1 / f1 / g1 / h5 / i2, 3 / j3 / k3 / 10.4-0.6 / m1.0-1.39 / n2, 6 / o1 / p3 / q1 Doyle et al., new subtype.

\section{Short triangle bowed inline \\ (Plate 2, Figures 4-6)}

Characters: Triangle (range of length to width ratios 1.0-1.39) with usually slightly convex margins and blunt apex. Inline with sides bowed in, its length about half the total length of the outline. Overall length $280-260 \mu \mathrm{m}$, width $140-210 \mu \mathrm{m}$.

Occurrence: In Paleocene sediments at Site 361.

subtype a9 / b1 / c1 / d1 / e1 / f1, 8 / g1 / h5 / i7 / j2, 3 / k5 / $1 \geq 0.75$ / m1.8-2.2 / n2 / o1 / p1, 2 / q2 (Curved flared triangle) Ramsey et al., in press, pl. 2 , fig. 13-15.

subtype a9 / b1 / c1 / d1 / e1 / f1, 2 / g1 / h5 / 19 / j9 / k8 / 10.75-0.95 / mz2.75 / n2 / o1 / p2 + a9 / b5 / c1 / d1 / e1 / f1 / g1 / h1 / i1 / j1 / k9 / 19 / m1, 4 / n1, 3 / 09 / p3 / q0.75-0.95 / r 22.75 / s0 / t2 / u1 Triangle sigmoid) Dunsworth et al., 1975, p. 857, pl. 1, fig. 11,12 ; pl. 2 , fig. 14 .

subtype a9 / b1 / c1, 15, (15+17) / d1 / e1, 2 / f1 / g3 / h5 / 16, 10 / j3 / $\mathrm{k8} / 10.1-0.3 / \mathrm{m}>2 / \mathrm{n2} / \mathrm{ol} / \mathrm{p1}, 2+\mathrm{a} 9 / \mathrm{b5} / \mathrm{c1} / \mathrm{d} 1 / \mathrm{e} 1,2$ / $\mathrm{f1} / \mathrm{g} 1 / \mathrm{h} 1,2$ / i1 / j4 / k2 / 12 / m4, 6 / n3 / o2, 4 / p2, 3 / q0 / r0 $/ \mathbf{s}>\mathbf{2} / \mathbf{t} \mathbf{~ / ~ u 1 ~ / ~ ( S t i p p l e d ~ t r i a n g l e ) ~ D u n s w o r t h ~ e t ~ a l . , ~ 1 9 7 5 , ~ p . ~ 8 5 7 , ~}$ pl. 1, fig. 19-21.

subtype a9 / b1 / c1 / d1 / e1 / f1 / g4 / h3 / i7 / j2 / k0 / 10 / m2-2.5 / $\mathrm{ng} / \mathrm{ol}$ / p1 / q1 (Triangle trailing margin) Ramsey et al., in press, pl. 2 , fig. 1,2 .

subtype a9 / b1 / c1 / d1 / e1 / f2 / g1 / h1, 2, 3 / i6 / j4 / k2, 4 / 10.2 0.4 / m1-2 / n3, 4, 5 / 02 / p1 (Curved triangle pointed margin) Doyle et al., 1974, p. 846, pl. 1G, fig. 3, 4; pl. 2J, fig. 1-3.

subtype a9 / b1 / c1 / d1 / e1 / f4 / g1 / h1 / i2 / j2 / k2 / 10.45-0.55 / m2.5-3.5 / n2 / o1, 5 / p2 Triangle inline halfway) Doyle et al., 1974 , p. 846 , pl. 1 H, fig. $1-3$; pl. $2 \mathrm{~K}$, fig. $5-8$.

subtype a9 / b1 / c1 / d1 / e1 / f4 / g1 / h2, 3, 4, 5 / i2, 3 / j2, 3 / k11 / $10 / \mathrm{m0} / \mathrm{n} 4,5,7,8 / 01 / \mathrm{p3} / \mathrm{q1}+\mathrm{a8} / \mathrm{b} 1,5 / \mathrm{cl} / \mathrm{d} 3 / \mathrm{e} 80-115$ 35-60 Doyle et al., new subtype.

Triangle square inline

(Plate 2, Figures 7-11)

Characters: Triangle with straight to slightly convex margins (in some specimens one margin has a prominent flexure) and blunt apex. Apex of inline approximately straight, transverse to the axis of the 
tooth. "Lateral shadows" present, rarely extending below level of apex of inline. Overall length $60-250 \mu \mathrm{m}$, width $80-110 \mu \mathrm{m}$.

Remarks: The "inline" of the $a 9 / b /$ morphotype is the "transverse line" of the $a 8$ / $b 5$ morphotype. Certain of the forms included in Wide triangle projection are very similar to the flexed form of Triangle square inline (see Plate 3, Figures 4, 6, 7), but differ in not having a straight margin above the flexure.

Occurrence: In late Cretaceous and possibly early Paleocene sediments at Site 361 .

subtype a9 / b1 / c1 / d1 / e1 / f4 / g1 / h4, 5 / i3, 5 / j3, 5 / k5+8 / 10.2-0.4 / m0.4-0.8 / n9 / $01 / \mathrm{p}^{3} / \mathrm{q} 1$ Doyle et al., new subtype.

\section{Wide crescent}

(Plate 2, Figures 12, 13)

Characters: Wide, arcuate form (range of length to width ratios 0.4-0.8) with pronounced "lateral shadow" paralleling the entire outline. Broad, undifferentiated area within inline. Overall length $90-$ $120 \mu \mathrm{m}$, width $130-170 \mu \mathrm{m}$.

Remarks: This form was recorded in an assemblage of uncertain age from DSDP-250-21, CC by Doyle et al. (1974, pl. 5, fig. 1). A rather similar form, but with straight sides and less obtusely rounded apex, occurs in younger samples.

Occurrence: In late Cretaceous and possibly early Paleocene sediments at Site 361 .

subtype a9 / b1 / c1 / d1 / el / f4 / g1 / h5 / i6 / j2, 6 / k5 / 10.5-0.75 / m1-1.5 / n9 / ol / p3 / q4 (Small triangle keeled edges) Ramsey et al., in press, pl. 2, fig. 19, 20.

subtype a9 / b1 / cl / d1 / e1 / f4 / g1 / h5 / i6 / j2, 3 / k8 / 10.5-0.7 / $\mathrm{m1.2-1.6} \mathrm{/} \mathrm{n9} \mathrm{/} \mathrm{o1} \mathrm{/} \mathrm{p1} \mathrm{/} \mathrm{q4} \mathrm{(Triangle} \mathrm{keeled} \mathrm{edges)} \mathrm{Ramsey} \mathrm{et} \mathrm{al.,}$ in press, pl. 3 , fig. 4,5 .

subtype a9 / b1 / cl / d1 / el / f4+8 / g1 / h5 / i2 / j2 / k5 / 10 / m1.6-2 / n9 / o1 / p1 / q4 (Straight triangle keeled edges) Ramsey et al., in press, pl. 3, fig. 1, 2 .

subtype a9 / b1 / cl / d1 / el / f4 +8 / g1 / h5 / i3 / j3 / k5 / 10.4-0.7 / m1-1.5 / n6, 7, 9 / ol / p3 / q4 (Wide triangle keeled edges) Ramsey et al., in press, pl. 2, fig. 18.

subtype a9 / b1 / c1 / d1 / el / f8 / g1 / h5 / i7 / j2, 3, 7 / k5 / $10.5-$ $0.75 / \mathrm{m1} .5-3 / \mathrm{n} 2 / 01 / \mathrm{p1-3} / \mathrm{q} 3$ /Flared triangle arcuate inline Ramsey et al., in press, pl. 2, fig. 6-9.

subtype a9 / b1 / c1 / d1 / el / f8 / g5 / h5 / il, 6 / j1, 4 / k5 / 10.3-0.5 / m1.5-2.5 / n9 / ol / pl / q1 (Triangle arcuate inline) Ramsey et al., in press, pl. 3 , fig. 3 .

subtype a9 / b1 / c1 / d1 / el / f9+(12, 13)+14 / g1 / h4, 5 / i2, 3 / j2, 3 / k11 / 10 / m0.9-1.4/n3, 4, 9/ol / p3 / q1 Doyle et al., new subtype.

\section{Striated blunt triangle}

(Plate 2, Figures 15-18)

Characters: Triangle (range of length to width ratios 0.9-1.4), with straight or slightly convex margins, and subparallel striations extending into upper half of outline and covering a large proportion of lower half of area. On rare specimens, enough of the tooth is preserved to permit definition of the inline which is broadly truncate upward. In three specimens preserving the inline, overall length is $210-340 \mu \mathrm{m}$ and maximum width $130-200 \mu \mathrm{m}$; in others, overall length is $110-270 \mu \mathrm{m}$, maximum width $100-190 \mu \mathrm{m}$.

Remarks: Although the characteristic striations are not clearly shown in the published illustration, this form has been recorded as an undescribed form by Ramsey et al. (in press, pl. 4, fig. 27) from late Cretaceous of DSDP Site 196.

Occurrence: In late Cretaceous and possibly early Paleocene sediments at Site 361 .

subtype a 9 / b1 / c1 / d1 / el / f10+(12, 13)+14 / g1 / h4, 5 / i2 / j2 / $\mathrm{k} 11 / 10 / \mathrm{ml} 1-1.6 / \mathrm{n} 3,4,9 / \mathrm{ol} / \mathrm{pl} / \mathrm{q} 1+\mathrm{a} 8 / \mathrm{b} 1,5 / \mathrm{cl} /$ d2 / e88-93 / 229-40 Doyle et al., new subtype.
Centrally striated triangle

(Plate 2, Figures 19-21)

Characters: Triangle (range of length to width ratios 1.1-1.6) with straight margins, and base with wide truncate indentation. Near the longitudinal axis, subparallel striations extend at least into upper half of tooth. Some specimens have a right-angle flexure at the base of one margin. Two specimens show an inline which is broadly truncate upward. Overall length of specimens without inline preserved 140-620 $\mu \mathrm{m}$, maximum width $90-290 \mu \mathrm{m}$.

Occurrence: In Maestrichtian and possibly early Paleocene sediments at Site 361 . The occurrences at Site 365 might be due to reworking.

subtype a9 / b1 / c6, 7 / d1 / el / f1, 4, 5 / g1 / h1, 3 / i2, 3 / j6 / k2 / $1<0.4$ / m1.5-2 / n1 / o1 / pl ( Triangle medium wing ) Doyle et al., 1974 , p. 846 , pl. 1G, fig. 6 ; pl. 2J, fig. 8-10.

subtype a9 / b1 / c9 / d1, 9, 13 / e1 / f2 +4 / g1 / h1 / i2 / j2 / k2, 3, 5 / 10.8-1.0 / m1.8-2.5 / $\mathbf{n 2 ~ / ~ o 1 ~ / ~ p 1 ~ ( ~ T r i a n g l e ~ n o t c h e d ~ c o r n e r ) ~ D o y l e ~}$ et al., 1974, p. 847 , pl. 2 J, fig. 12-14.

subtype a9 / b1 / c9, 13 / dl / el / f4+(6, 7) / g1 / h4 / i2 / j2 / k7, 8 / 10.2-0.6/m1.6-2.8/n2/o1, $2 / \mathrm{pl}+\mathrm{a} 9 / \mathrm{b} 5 / \mathrm{c8}, 12 / \mathrm{d} 1 / \mathrm{el}$ / f1 / g1 / h1 / i2 +4 / j1 / k2 / $12 / \mathrm{m2} / \mathrm{n2} / 09 / \mathrm{p3} .8 / \mathrm{q} 0.2-0.6$ / r1.6-2.8 / s0 / t1 / ul (Triangle with base angle) Dunsworth et al., 1975 , p. 857 , pl. 1 , fig. 15,16 .

subtype a9 / b1 / c13 / d13 / el / f1, (10+12+14) / g1 / h5 / 2 i2 / j2, 3 / k3, 8 / 10.4-0.6 / m1.2-1.6 / n2 / ol / p1 / q1 Doyle et al.. new subtype.

Beveled triangle mid inline

(Plate 3, Figures 1, 2)

Characters: Triangle (range of length to width ratios 1.2-1.6), with the basal corners beveled. Inline with sides bowed in, or approximately parallel to outline, reaching approximately half the height of the outline. Overall length $160-300 \mu \mathrm{m}$, width $90-180 \mu \mathrm{m}$.

Remarks: This subtype is defined in such a way as to exclude relatively narrower, undescribed forms that co-occur, since the latter grade into a still narrower undescribed form occurring in younger assemblages.

Occurrence: In early Paleocene at Site 361.

subtype a9 / b1 / c13 / d13 / el / f1 / g1 / h5 / i2 / j2 / k8 / 10.1-0.3 /

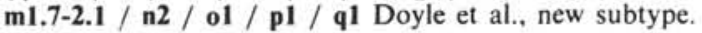

\section{Beveled triangle high inline}

(Plate 3, Figures 4, 5)

Characters: Triangle (range of length to width ratios 1.7-2.1), with the basal corners beveled. Inline parallel to the straight margins of the outline, extending at least 0.75 of the distance from its straight base to the apex of the outline. Overall length $220-360 \mu \mathrm{m}$, width $110-$ $170 \mu \mathrm{m}$.

Occurrence: In Paleocene sediments at Site 361.

subtype a9 / b1 / c13 / d13 / el / f4 / g1 / h1 / i2 / j2 / k2 / 1<0.6 / $\mathrm{m} 2.0-3.0 / \mathrm{n} 3 / 03 / \mathrm{p} 2$ (Triangle pointed margin ends) Doyle et al., 1974 , p. 847 , pl. IG, fig. 7 ; pl. 2 K, fig. 1-4.

subtype a9 / b1 / c15, 17 / d15, 17 / e1, 2 / f1 / g1 / h5 / i2, 3 / j2, 3 / $\mathrm{k9} / \mathrm{10.25-0.5} / \mathrm{m0.5}-1.4 / \mathrm{n1} / \mathrm{ol} / \mathrm{pl}$ / Small triangle crenate margin) Dunsworth et al., 1975, p. 857 , pl. 2, fig. 4,5 .

subtype a9 / b1 / c19 / d1, 19 / el / f1 / g4 / h3, 4, 5 / i2, 3, 10 / j2, 7,

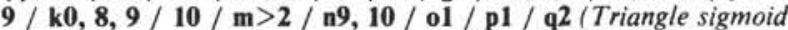
rough) Ramsey et al., in press, pl. 1, fig. $1-11,14,15$.

subtype a9 / b5 / c1 / d1 / el / f1 / g1 / h1 / il / j1 / k2 / 12 / ml-4 / $\mathrm{n} 1-4 / 02 / \mathrm{p} 2,3 / \mathrm{q0} / \mathrm{r0} / \mathrm{s}<2.75$ / 1,2 / u1 / v1 (Triangle small top) Ramsey et al., in press, pl. 3, fig. 13-17.

subtype a9 / b5 / cl / d1 / el / f1 / g1 / h1 / il / j1 / k2 / 12 / m4 / n3 / $02 / \mathrm{p2} / \mathrm{q0} / \mathrm{r0} / \mathrm{s}>2.75 / \mathrm{t1} / \mathrm{ul} / \mathrm{v1}$ / Narrow curved triangle small top) Ramsey et al., in press, pl. 3, fig. 11, 12. 
subtype a9 / b5 / c1 / d1 / e1 / f1 / g1 / h1 / i1 / j1 / k2, 6 / 13 / m2, 4 / n3 / o2 / p7 / q0.4-0.6/ r1.5-2.6 / s0 / t2 + a9 / b1 / c1 / d1 / e1 / f1 / g1 / h1 / i2, 6 / j3 / k6 / 10.4-0.6 / m1.5-2.6 / n2 / o1 / p2 (Curved triangle inline constricted) Doyle et al., 1974, p. 847, pl. 11 , fig. 7 ; pl. $2 \mathrm{~L}$, fig. 7,8 .

subtype a9 / b5 / c1 / d1 / e1 / f1 / g1 / h1 / i1, 4, 10 / j1 / k3 / 13 / $\mathrm{m1}, 4 / \mathrm{n1}, 4 / 04 / \mathrm{p} 6 / \mathrm{q} 0 / \mathrm{r} 0.7-0.9 / \mathrm{s} 1.4-1.7 / \mathrm{t3} / \mathrm{ul} / \mathrm{v} 4$ + a9 / b1 / c1 / d1 / el / f8 / g1 / h5 / i3 / j3 / k5 / 10 / m0.7-0.9 / n9 / o1 / p3 / q4 (Capped triangle) Ramsey et al., in press, pl. 3, fig. $18-21$.

subtype a9 / b5 / c1 / d1 / e1 / f1 / g1 / h1 / i(1, 5) + 4 + [1, $(11+15+16)] / \mathrm{j} 1 / \mathrm{k3} / \mathrm{13} / \mathrm{m2}, 3 / \mathrm{n2}, 3 / 04,7 / \mathrm{p3}+6 / \mathrm{q} 0.4-0.9$ / r0.4-0.7 / s1-1.9 / t3 / u1 / v1 + a9 / b1 / c1 / d1 / el / f(1, 4) $+[1,(9+13+14)] / g 1 / \mathrm{h} 4,5 / \mathrm{i} 3 / \mathrm{j3} / \mathrm{k5}+8 / 10 / \mathrm{m} 0.9-1.4 /$ n7, 8, 9 / o1 / p3 / q1 Doyle et al., new subtype.

Narrower crescent

(Plate 3, Figures 6-11)

Characters: Triangle with slightly convex margins and bluntly rounded apex (range of length to width ratios below transverse line 11.9 , and above transverse line 0.4-0.7). Transverse line broadly curved, briefly reflexed near its base. Some specimens show numerous subparallel striations above the transverse line. Many specimens lack the part below the transverse line. Overall length of $a 9 / b 5$ is $130-230$ $\mu \mathrm{m}$, width $60-120 \mu \mathrm{m}$. Overall length of $a 9 / \mathrm{bl}$ is 80-100 $\mu \mathrm{m}$, width $30-90 \mu \mathrm{m}$.

Remarks: This form is somewhat similar to "the other view (at $90^{\circ}$ )" (Doyle et al., 1974, p. 848) of Triangle complex transverse line.

Occurrence: In Maestrichtian through Paleocene at Site 361, and has been observed in younger sediments.

subtype a9 / b5 / c1 / d1 / e1 / f1 / g1 / h1 / i4 +5 / j1 / k2, 6 / 12,3 / $\mathrm{m1} / \mathrm{n1} / \mathrm{o6}, 9$ / p8+9 / q0.2-0.4 / r1.1-2.0 / s0 / t3 / u1 / $\mathrm{v1}+\mathrm{ag} / \mathrm{bl} / \mathrm{c1} / \mathrm{d1} / \mathrm{el} / \mathrm{f4} / \mathrm{gl} / \mathrm{h2}, 3,4,5 / \mathrm{i2}, 6 / \mathrm{j2}, 3$ / $\mathrm{k}(\mathbf{7}+8)+10 / 10.25-0.5 / \mathrm{m1.1-2.2} / \mathrm{n7}, 8,9 / \mathrm{ol} / \mathrm{p3} / \mathrm{q} 1$ Doyle et al., new subtype.

\section{Blunt triangle dendritic inline}

(Plate 3, Figures 12-15)

Characters: Triangle with blunt apex, margins straight or slightly concave or convex above transverse line, and with "lateral shadows." Inline usually parallel-sided, markedly narrower than outline, and its apical part dendritically branched. Overall length $140-340 \mu \mathrm{m}$, width $70-170 \mu \mathrm{m}$.

Remarks: This form has previously been recorded from a sample of unknown age by Doyle et al. (1974, pl. 5, fig. 12).

Occurrence: In late Cretaceous sediments at Site 361 .

subtype a9 / b5 / c1, 4 / d1 / e1, 3 / f1 / g1 / h1 / i5 / j2 / k2, 7 / 12 / $\mathrm{m2}, 4$ / n2, 3 / o1, 2 / p2, 3, 6 / q0 / r >0.5 / s>3 / 2 (Narrow triangle cross-hachured) Doyle et al., 1974, p. 847, pl. 2L, fig. 1-

subtype a9 / b5 / c1 / d1 / e1 / f1 / g1 / h1 / i8 / j2 / k2 / 12 / m2 / n2 / $02 / \mathrm{p2} / \mathrm{q} 1 / \mathrm{r} 1.7-2 / \mathrm{s} 0 / \mathrm{t} 1 / \mathrm{u} 1 / \mathrm{v} 1+\mathrm{ag} / \mathrm{b} 1 / \mathrm{c1} / \mathrm{d} 1 / \mathrm{e} 1 /$ $\mathrm{f6} / \mathrm{g1} / \mathrm{h5} / \mathrm{i2} / \mathrm{j2} / \mathrm{k0} / \mathrm{l1} / \mathrm{m1.7-2} / \mathrm{n2} / \mathrm{ol} / \mathrm{p1} / \mathrm{q} 1$ (Striated triangle) Ramsey et al., in press, pl. 3, fig. 22-24.

subtype a9 / b5 / c1 / d1 / e1 / f1 / g1, 2 / h2 / i1, 4/ j1 / k2 / 12 / m2 / $\mathrm{m2}$ / 05, 6 / p3 / q0.2-0.5 / r1-1.5 / s0 / t1 (Triangle with canals) Doyle et al., 1974, p. 848 , pl. 11 , fig. 13,14 ; pl. 2 L, figs. $13-15$.

subtype a9 / b5 / c1 / d1 / e1 / f1 / g1 / h2 / i4t(1, 6) / j1 / k2, 3 / 12 3 / m2 / n2 / 04 / p4, 8 / q0.5-0.7/ r1.5-2.3 / s0 / t1 / u1 / $\mathrm{v1}+\mathrm{ag} / \mathrm{b1} / \mathrm{c1} / \mathrm{d1} / \mathrm{el} / \mathrm{f4} / \mathrm{g} 1 / \mathrm{h5} / \mathrm{i2}, 3 / \mathrm{j2}, 3$ / k3, 7 / 10.5-0.7 / m1.5-2.3 / n6, 7 / o1 / p1 / q1 / Doyle et al., new subspecies.

Triangle curved base

(Plate 3, Figures 16, 17)

Characters: Triangle (range of length to width ratios 1.5-2.3) with "lateral shadows." Transverse line curved, terminating at the margins. Inline usually with sides bowed in, its apex within 0.25 and 0.5 of the distance between top of transverse line or base of inline and apex of tooth. Canals are present below transverse line. Overall length for $a 9 / b 5,240-400 \mu \mathrm{m}$, width $100-140 \mu \mathrm{m}$. Overall length for $a 9 / b l, 180-300 \mu \mathrm{m}$; width $90-120 \mu \mathrm{m}$.

Occurrence: In late Paleocene sediments at Site 361, and has been observed in Eocene assemblages.

subtype a9 /b5 / c1 / d1 / e1 / f1 / g2 / h2 / i4 / j1 / k2, 4, 6 / 12, 4 / $\mathrm{m1} / \mathrm{n1} / 04$ / p3 / q0.2-0.4 / r1.5-2.5 / s0 / t1 (Triangle transverse line across) Doyle et al., 1974, p. 848, pl. 1J, fig. 1; pl. 2M, fig. 6-9.

subtype a9 / b5 / c1 / d1 / e3 / f1 / g1 / h1 / 11 / j1 / k2, 7 / 12 / m2, 4 / n3 / o1, 2 / p2, 3 / q0 / r >1 / s >3 / t2 (Triangle with triangular projection) Doyle et al., 1974, p. 847, pl. 1H, fig. 16-19; pl. 2K, fig. 17-21.

subtype a9 / b5 / c1 / d1 / e3 / f1 / g1 / h1 / i1 / j3 / k2 / 12 / m2 / n2, 3 / o2, 4/ p2 / q0 / r0.7-0.9/ s1, 2, 3 / 2 / u1 / v1 + a9 / b5 / c4 / d1 / e1 / f1 / g1 / h1 / i1 / j3 / k2 / 12 / m2 / n2, 3 / o10 / p2, 6 / q0 / r0.7-0.9 / s1, 2, 3 / t2 / u1 / v1 Doyle et al., new subtype.

\section{Wide triangle projection}

(Plate 3, Figures 18-26)

Characters: Triangles with a simply curved or straight transverse line above a triangular projection or with a flexed transverse line terminating below the triangular projection on one margin. Apical triangular part above the transverse line is moderately wide (range of length to width ratios $0.7-0.9$ ). Some specimens show distinct striations parallel to the margins, below transverse line. Overall length $150-400 \mu \mathrm{m}$, width $40-110 \mu \mathrm{m}$.

Remarks: This form is the same as Type $\mathrm{H}$ of Helms and Riedel (1971, pl. 2, fig. 5), and possibly also their Type J (ibid., pl. 2, fig. 6).

Occurrence: In late Cretaceous and possibly Paleocene sediments at Site 361 .

Type a9 / b7 (Rounded apex triangle) Doyle et al., 1974, p. 848, pl. 1J, fig. 7-10; pl. 2M, fig. 12-15.

subtype a9/ b6 / c2-5 / d2 / e1 Doyle et al., new subtype.

\section{Triangular toothed \\ (Plate 4, Figures 1-4)}

Characters: Roughly triangular to arcuate forms with dentate edge which is approximately paralleled by a distinct undulating line. Usually 3-5 projections, the shape of the middle (largest) one an unmodified triangle. The inline extends into the middle projection. Apex of projections usually broken off. Overall length approximately $100-300 \mu \mathrm{m}$, width $120-400 \mu \mathrm{m}$.

Remarks: This subtype has been recorded by Ramsey et al. (in press, pl. 1, fig. 12, 13) from the Tithonian of Sicily.

Occurrence: In late Cretaceous sediments at Site 361 .

\section{ACKNOWLEDGMENTS}

This research was supported partly by NSF Grant GA40158 , and partly by the University of California. M.A. Hanger ably typed the manuscript and S. Hill-Minchilli and C. Edgerton helped with the proofreading.

\section{REFERENCES}

Doyle, P.S., Kennedy, G.G., and Riedel, W.R., 1974. Stratignathy. In Davies, T.A., Luyendyk, B.P., et al., Initial Reports of the Deep Sea Drilling Project, Volume 26: Washington (U.S. Government Printing Office), p. 825-905.

Doyle, P.S., Dunsworth, M.J., and Riedel, W.R., in press. Reworking of ichthyoliths in eastern tropical Pacific sediments: Deep-Sea Res.

Dunsworth, M.J., Doyle, P.S., and Riedel, W.R., 1975. Ichthyoliths from some NW Pacific sediments, DSDP Leg 32. In Larson, R.L., Moberly, R.M., et al., Initial Reports of the Deep Sea Drilling Project, Volume 32: Washington (U.S. Government Printing Office), p. 853-863. 
Helms, P. B. and Riedel, W.R., 1971. Skeletal debris of fishes. In Winterer, E.L., Riedel, W.R., et al., Initial Reports of the Deep Sea Drilling Project, Volume 7: Washington (U.S. Government Printing Office), p. 1709-1720.

Ramsey, C.A., Doyle, P.S., and Riedel, W.R., in press. Ichthyoliths in late Mesozoic pelagic sediments, mainly from Italy: Micropaleontology.

\section{LIST OF NEW FORMS}

Table 3 is a numerically arranged listing of the new subtypes described herein. Below is an alphabetically arranged list of the colloquial names of all the new subtypes.

Centrally striated triangle

Beveled triangle high inline

Beveled triangle mid inline

Blunt triangle dendritic inline

Narrower crescent

Plain and lined lanceolate

Pointed and skirted

Prominence with wye-line

Prominent polygon

Short triangle bowed inline

\author{
Striated blunt triangle \\ Triangle concave base \\ Triangle curved base \\ Triangle long inline \\ Triangle square inline \\ Triangular toothed \\ Wide crescent \\ Wide triangle projection
}

\section{PLATES}

In the explanations to the figures, the sample numbers, and slide designations (in the form S1.4, etc.) indicate preparations in our collection at Scripps Institution of Oceanography and designations in the forms U19/2 or S76 indicate England Finder positions of the illustrated specimens on the slides.

A standard magnification of $165 \times$ is used instead of the 110X used in past studies because many of the ichthyoliths found in cores older than Paleocene at Site $36 \mathrm{I}$ appear to be smaller than those found in the Cenozoic. 


\section{PLATE 1}

All figures are magnified $165 \times$, unless otherwise specified.

Figures 1-4

$$
\begin{aligned}
& \text { a3, } 4 / \mathrm{bl} / \mathrm{cl}, 2,3 / \mathrm{d} 5,(4+5) / e 2 / f 2 / \mathrm{gl}+8 / \\
& \text { h2 } \\
& \text { Prominence with wye-line. } \\
& \text { 1. } 361-10-6,29-36 \mathrm{~cm}, \mathrm{~S} 1.6, \mathrm{R} 24 / 2 . \\
& \text { 2. } 361-12-5,84-90 \mathrm{~cm}, \mathrm{~S} 1.4, \mathrm{R} 36 / 2 ; 106 \times . \\
& \text { 3. } 361-10-2,92-95 \mathrm{~cm}, \mathrm{~S} 1.2, \mathrm{U} 26 . \\
& \text { 4. } 361-25-2,34-41 \mathrm{~cm}, \mathrm{~S} 1.5, \mathrm{~B} 46 / 4 \text {. }
\end{aligned}
$$

Figures 5-7 $a 3,5 / b 8 / c 5,6,7,8 / d 0.70-1.0 / e 60-100$. Prominent polygon.
5. 361-13-1, 79-85 cm, S1.3, S37/3.
6. $361-11-2,16-21 \mathrm{~cm}, \mathrm{Sl} .1, \mathrm{~B} 25$.
7. $361-12-3,21-27 \mathrm{~cm}, \mathrm{Sl} .2, \mathrm{~W} 10$.

Figures 8-11 a3, $4 / b l, 2 / c 2,3,4 / d l, 2,3 / e l / f 2+3 / g l+8$ / hl.

Pointed and skirted.

8. 361-11-2, 16-21 cm, S1.4, F36; 106×.

9. 361-10-6, 29-36 cm, Sl.1, W36.

10. $361-9-6,132-138 \mathrm{~cm}, \mathrm{Sl} .1, \mathrm{~T} 22$.

11. 361-11-2, 16-2I cm, Sl.4, D24; 106x.

Figures 12-15 $a 4 / b l, 2 / c 2 / d l, 2,3 / e 2 / f l(2+3) / g l+2 /$ hl.

Plain and lined lanceolate.

12. $361-10-2,92-95 \mathrm{~cm}, \mathrm{~S} 1.5, \mathrm{~F} 36$.

13. 361-9-6, 132-138 cm, Sl.3, L20/2; 106×.

14. $361-10-2,92-95 \mathrm{~cm}, \mathrm{SI} .3, \mathrm{~B} 10$.

15. $361-12-3,21-27 \mathrm{~cm}, \mathrm{Sl} .1, \mathrm{H} 39 / 0$.

Figures 16, $17 a 9 / b l / c l / d l / e l / f l / g l / h 2,4,5 / i 2,6 / j 2 /$ $k 8 / 10.2-0.3 / \mathrm{ml} .9-2.5 / \mathrm{n} 6,7,8 / \mathrm{ol}, 3 / \mathrm{pl}, 2 /$ $q l$.

Triangle concave base.

16. 361-9-2, 128-132 cm, S1.4, P28.

17. Same sample, Sl.13, C27/3: 106×. 
PLATE 1
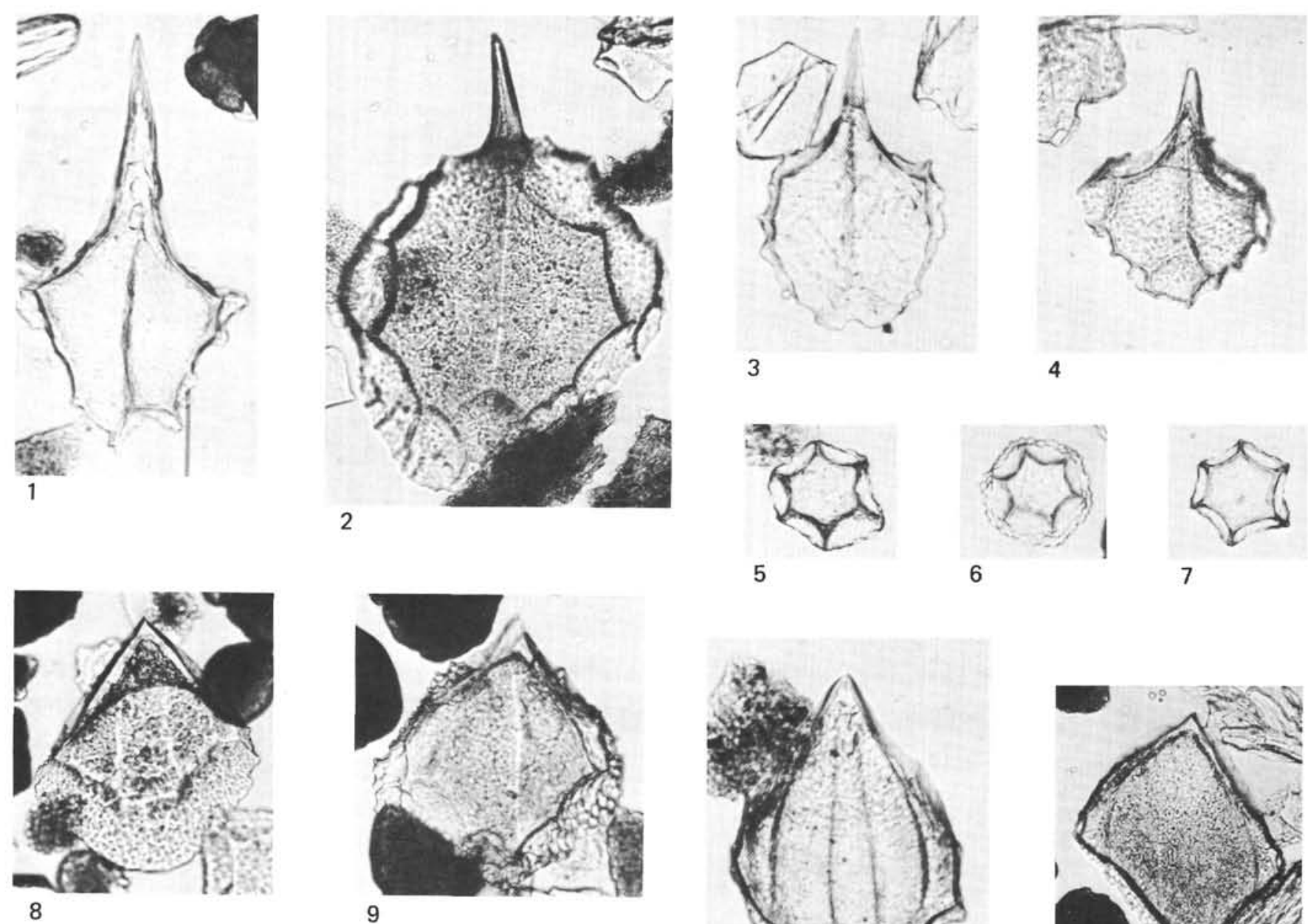

5
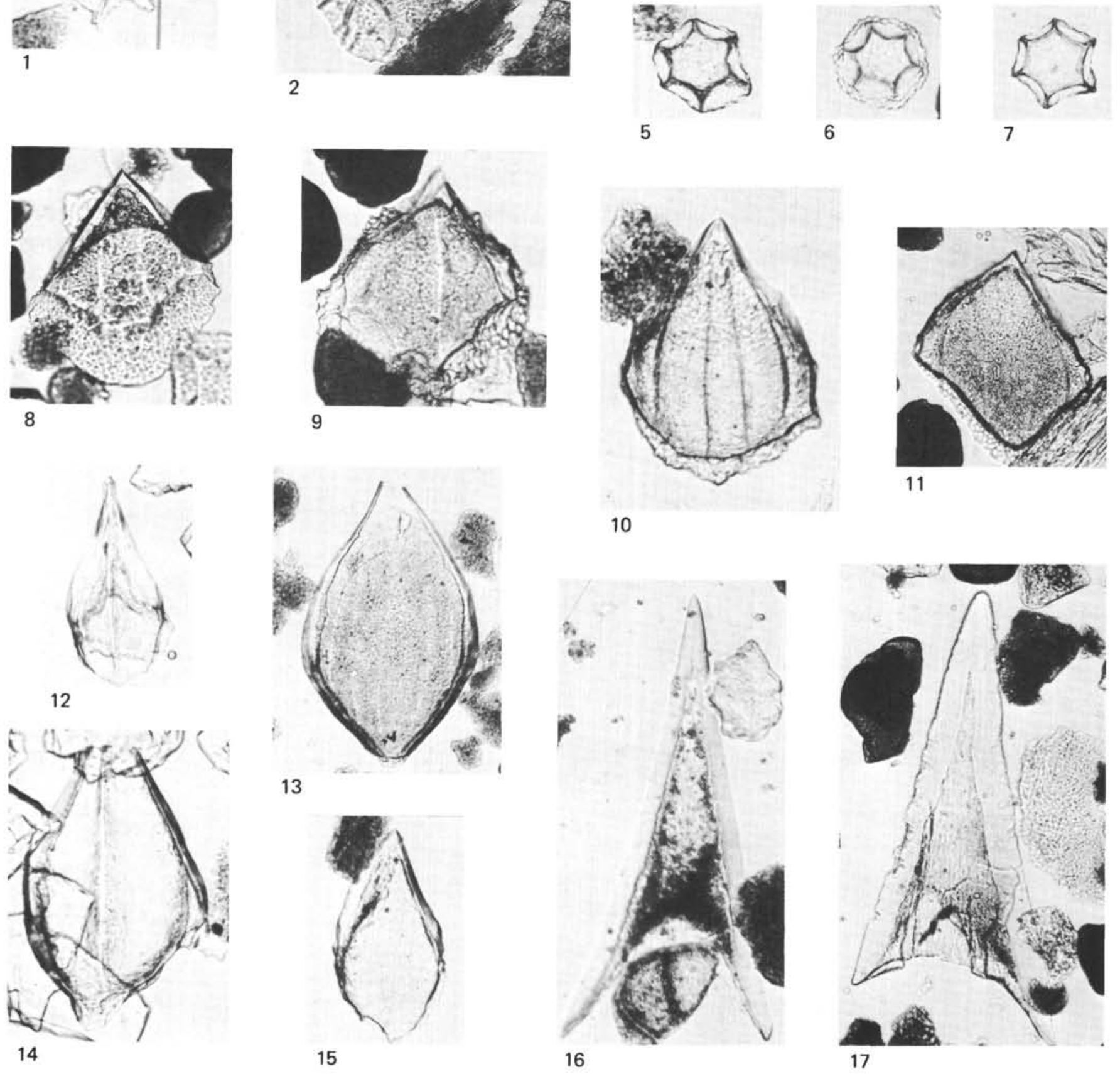


\section{PLATE 2}

All figures are magnified $165 \times$.

Figures 1-3 $a 9 / b l / c l / d l / e l / f l / g l / h 5 / i 2,6 / j 2,3 /$ $k 7.8 / 10.2-0.5 / m 2.5-4.9 / n 2 /$ ol / p2 / q1.

Triangle long inline.

1. 361-11-5, 36-42 cm, Sl.1, T17.

2. Same sample, Sl.4, U15/4.

3. Same sample, Sl.4, O36.

Figures 4-6

a 9 / bl / cl / dl / el / fl / $\mathrm{gl} / \mathrm{hs} / \mathrm{i2}, 3 / \mathrm{j} 3 / \mathrm{k3} /$ 10.4-0.6 / ml.0-1.39 / n2, 6 / ol / p3 / ql.

Short triangle bowed inline.

4. $361-9-2,128-132 \mathrm{~cm}, \mathrm{Sl} .1, \mathrm{~T} 18 / 4$.

5. $361-9-4,112-118 \mathrm{~cm}, \mathrm{Sl} .13, \mathrm{~V} 36 / 2$.

6. $361-10-2,92-95 \mathrm{~cm}, \mathrm{Sl} .7, \mathrm{~T} 32 / 2$.

Figures 7-11 $a 9 / b l / c l / d l / e l / f 4 / g l / h 2,3,4,5 / i 2,3 /$ j2, 3 / $\mathrm{kll} / \mathrm{l} 10$ / $\mathrm{m0} / \mathrm{n4}, 5,7,8$ / ol / $\mathrm{p} 3$ / $q l+a 8 / b l, 5 / c l / d 3 / e 80-115 / f 35-60$.

Triangle square inline.

7. 361-12-5, 84-90 cm, Sl.1, P31.

8. 361-12-3, 21-27 cm, Sl.6, Q33/1.

9. 361-11-2, 16-21 cm, Sl.1, O27.

10. 361-10-6, 29-36 cm, Si.1, G35/1.

11. $361-12-5,84-90 \mathrm{~cm}, \mathrm{SI} .3, \mathrm{~F} 30$.

Figures 12-14 $a 9 / b l / c l / d l / e l / f 4 / g l / h 4,5 / i 3,5 / j 3,5 /$ $k 5+8 /$ l0.2-0.4 / m0.4-0.8 / n9 / ol / p3 / ql.

Wide crescent.

12. 361-10-6, 29-36 cm, Sl.2, C24.

13. $361-12-2,22-28 \mathrm{~cm}, \mathrm{Sl} .4, \mathrm{M} 11$.

14. $361-12-3,21-27 \mathrm{~cm}, \mathrm{Sl} .6, \mathrm{D} 15$.

Figures 15-18 $a 9 / b l / c l / d l / e l / f 9+(12,13)+14 / g l / h 4,5$ / i2, 3 / j2, 3 / kll / 10 / m0.9-1.4 / n3, 4, 9 / ol / p3 / q1.

Striated blunt triangle.

15. 361-15-2, 127-134 cm, Sl.3, Q14.

16. $361-11-2,16-21 \mathrm{~cm}, \mathrm{~S} 1.2, \mathrm{D} 23$.

17. $361-16-2,14-22 \mathrm{~cm}, \mathrm{Sl} .1, \mathrm{E} 30$.

18. $361-12-5,84-90 \mathrm{~cm}, \mathrm{Sl} .3, \mathrm{~W} 10$.

Figures 19-2l $a 9 / \mathrm{bl} / \mathrm{cl} / \mathrm{dl} / \mathrm{el} / \mathrm{flO}+(12,13)+14 / \mathrm{gl} / \mathrm{h} 4$. 5 / $i 2$ / j2 / kll / lo / ml.l-l.6 / n3, 4, 9 / ol / pl / $q l+a 8 / b l, 5 / c l / d 2 / e 88-93 / f 29-40$.

Centrally striated triangle.

19. $361-10-6,29-36 \mathrm{~cm}, \mathrm{Sl} .3, \mathrm{~F} 37$.

20. $361-11-2,16-21 \mathrm{~cm}, \mathrm{Sl} .1, \mathrm{~V} 24$.

21. $361-11-5,36-42 \mathrm{~cm}, \mathrm{~S} ! .2, \mathrm{X} 26$. 
PLATE 2
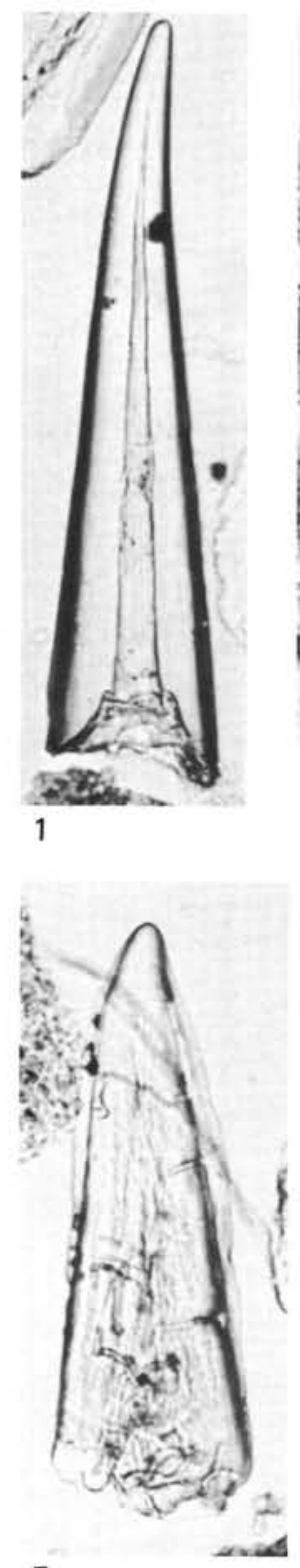

7

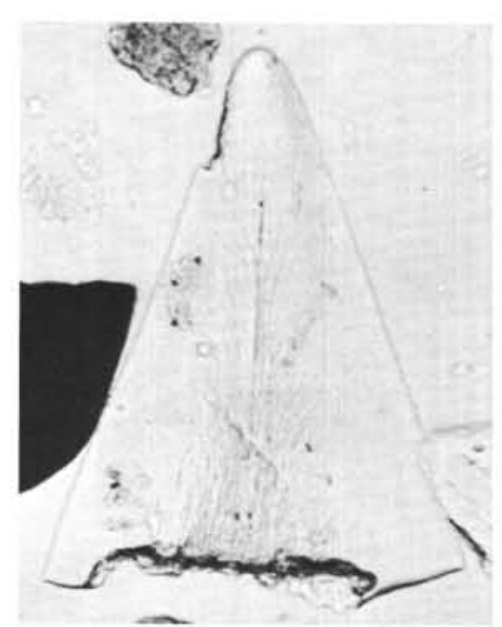

19

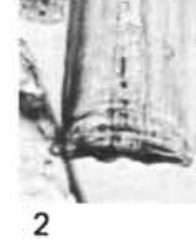

9
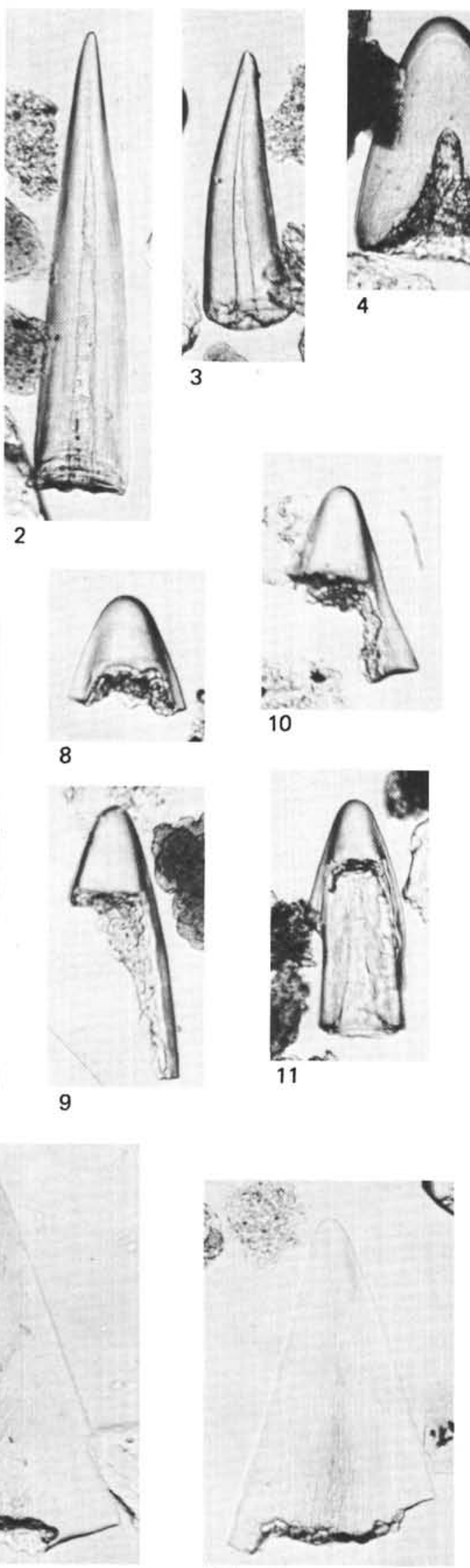

20
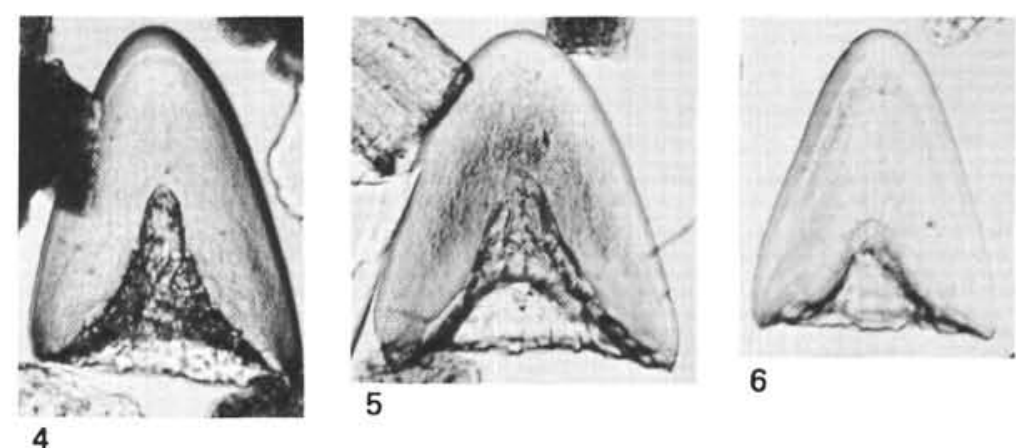

6

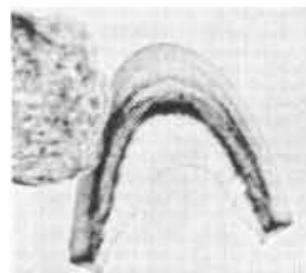

12

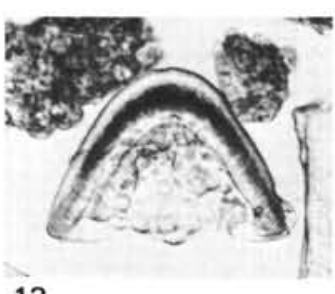

13
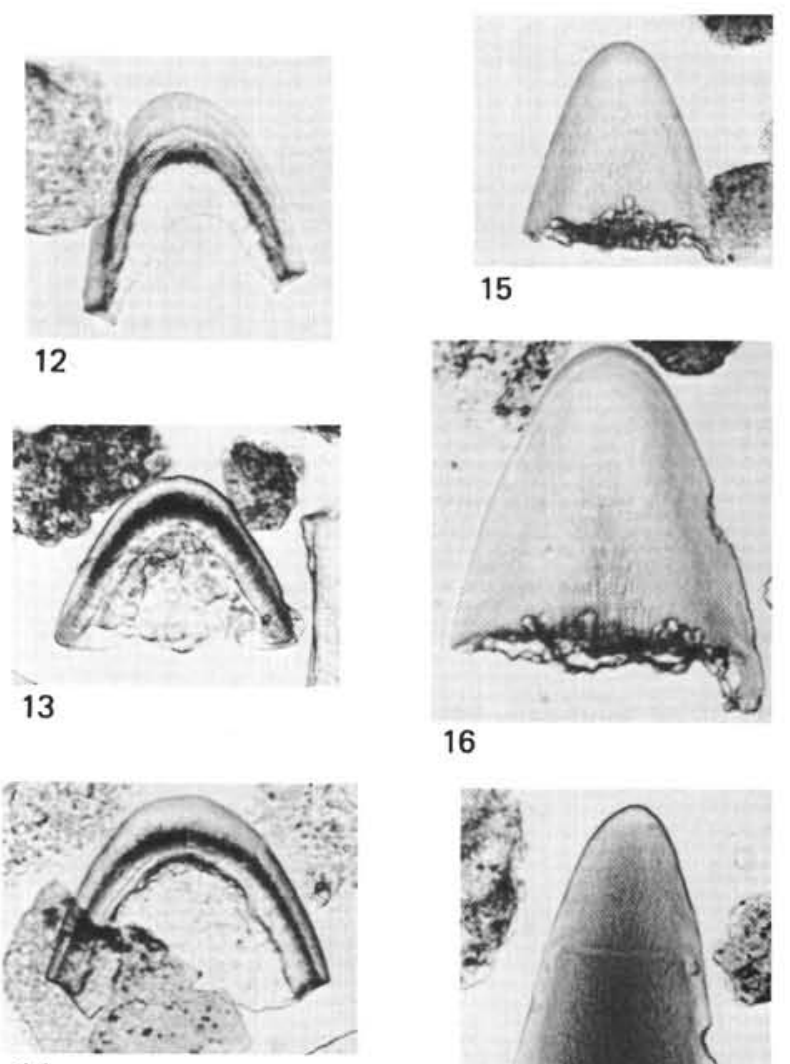

14

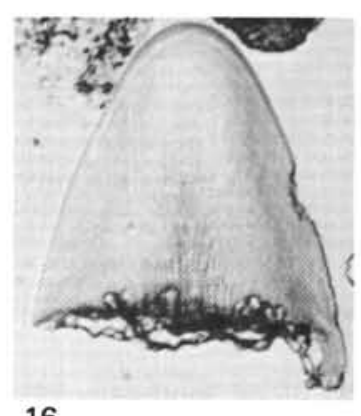

16

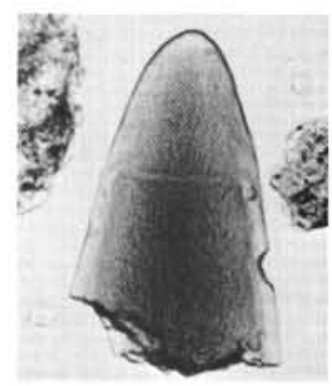

17

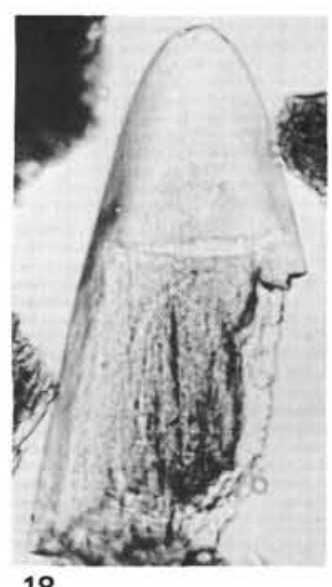




\section{PLATE 3}

All figures magnified $165 \times$.

Figures 1, 2

Figure 3

Figures 4, 5

Figures 6-11

Figures 12-15

Figures 16, 17

Figures 18-26

Figure 27

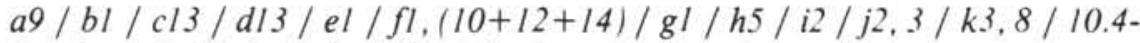
$0.6 / \mathrm{ml} .2-1.6 / \mathrm{n} 2 / \mathrm{ol} / \mathrm{pl} / \mathrm{ql}$.

Beveled triangle mid inline.

1. $361-10-2,92-95 \mathrm{~cm}, \mathrm{Sl} .9, \mathrm{~L} 36$.

2. Same sample, S1.5, P37.

Undescribed form.

361-9-6, 132-138 cm, Sl.3, J20.

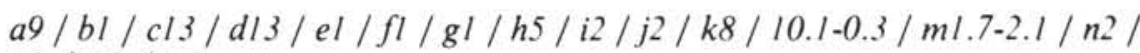
ol / pl / ql.

Beveled triangle high inline.

4. 361-9-6, 132-138 cm, Sl.1, T21.

5. 361-9-4, 112-118 cm, S1.9, J29/2.

$\mathrm{a} 9 / \mathrm{b5} / \mathrm{cl} / \mathrm{dl} / \mathrm{el} / \mathrm{fl} / \mathrm{gl} / \mathrm{hl} / \mathrm{i}(l, 5)+4+[l,(l l+15+16)] / \mathrm{jl} / \mathrm{k} 3 /$ $13 / \mathrm{m} 2,3 / \mathrm{n} 2,3 / 04,7 / p 3+6 / q 0.4-0.9 / \mathrm{r} 0.4-0.7 / s l-1.9 / \mathrm{t} 3 / \mathrm{ul} / \mathrm{vl}+$ a9 / bl / cl / dl / el / f $(l, 4)+[l,(9+13+14)] / g l / h 4.5 / i 3 / j 3 / k 5+8 /$ 10 / m0.9-l.4 / n7, 8, 9 / ol / p3 / ql.

Narrower crescent.

6. $361-12-5,84-90 \mathrm{~cm}, \mathrm{Sl} .5, \mathrm{~S} 18$.

7. $361-12-3,21-27 \mathrm{~cm}, \mathrm{Sl} .3, \mathrm{~K} 19 / 1$.

8. $361-12-2,22-28 \mathrm{~cm}, \mathrm{Sl} .2, \mathrm{G} 36$.

9. 361-13-1, 79-85 cm, Sl.3, U8/1.

10. Same sample, $\mathrm{Sl} .5, \mathrm{D} 27 / 1$.

11. $361-11-5,36-42 \mathrm{~cm}, \mathrm{Sl} .1, \mathrm{~N} 25$.

a9 / b5 / cl / dl / el / fl / gl / hl / i4 +5 / jl / k2,6/l2,3/ml / nl / o6, 9 /p8+9/q0.2-0.4/rl.l-2.0/s0/t3/ul/vl $+a 9 / \mathrm{bl} / \mathrm{cl} / \mathrm{dl} / \mathrm{el} / \mathrm{f} 4$

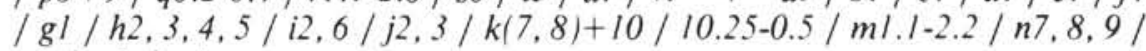
ol / p3 / ql.

Blunt triangle dendritic inline.

12. $361-16-2,14-22 \mathrm{~cm}, \mathrm{Sl} .1, \mathrm{~F} 34$.

13. $361-12-5,84-90 \mathrm{~cm}, \mathrm{Sl} .2$, U20/1.

14. $361-14-2,19-24 \mathrm{~cm}, \mathrm{Sl} .7, \mathrm{~L} 25$.

15. $361-16-2,14-22 \mathrm{~cm}, \mathrm{Sl} .2, \mathrm{G} 26$.

$a 9 / b 5 / \mathrm{cl} / \mathrm{dl} / \mathrm{el} / \mathrm{fl} / \mathrm{gl} / \mathrm{h} 2 / \mathrm{i4}+(l, 6) / \mathrm{jl} / \mathrm{k2}, 3 / \mathrm{l}, 3 / \mathrm{m2} / \mathrm{n2} /$ $04 / p 4.8 / q 0.5-0.7 / \mathrm{rl} .5-2.3 / \mathrm{sO} / \mathrm{tl} / \mathrm{ul} / \mathrm{vl}+\mathrm{a} 9 / \mathrm{bl} / \mathrm{cl} / \mathrm{dl} / \mathrm{el} /$ $\mathrm{f4} / \mathrm{gl} / \mathrm{h} 5$ / i2, 3 / j2, 3 / k3, 7 / l0.5-0.7/ ml.5-2.3 / n6. 7 / ol / pl / ql.

Triangle curved base.

16. $361-9-4,112-118 \mathrm{~cm}, \mathrm{Sl} .3, \mathrm{R} 23$.

17. $361-9-2,128-132 \mathrm{~cm}, \mathrm{Sl} .7, \mathrm{D} 28$.

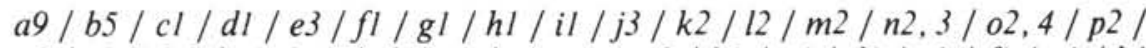

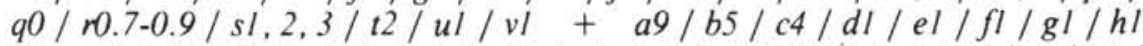
/ il / j3 / k2 / l2 / m2 / n2, 3/ olo / p2, 6 / q0 / r0.7-0.9/sl, 2, 3/ t2 / ul / $v l$.

Wide triangle projection.

18. $361-16-2,14-22 \mathrm{~cm}, \mathrm{Sl} .3, \mathrm{H} 21 / 4$.

19. 361-14-2, 19-24 cm, Sl.4, N23/4.

20. $361-16-2,14-22 \mathrm{~cm}, \mathrm{Sl} .6, \mathrm{~N} 27 / 4$.

21. 361-11-2, 16-21 cm, Sl.5, W37/4.

22. Same sample, S1.3, S20.

23. $361-12-3,21-27 \mathrm{~cm}, \mathrm{Sl} .4, \mathrm{E} 30$.

24. $361-12-5,84-90 \mathrm{~cm}, \mathrm{Sl} .2, \mathrm{~J} 12 / 4$.

25. 361-13-1, 79-85 cm, Sl.5, W40/2.

26. $361-13-1,79-85 \mathrm{~cm}, \mathrm{Sl} .2, \mathrm{~T} 10 / 4$.

Undescribed form.

361-16-2, 14-22 cm, Sl.5, A35. 
PLATE 3
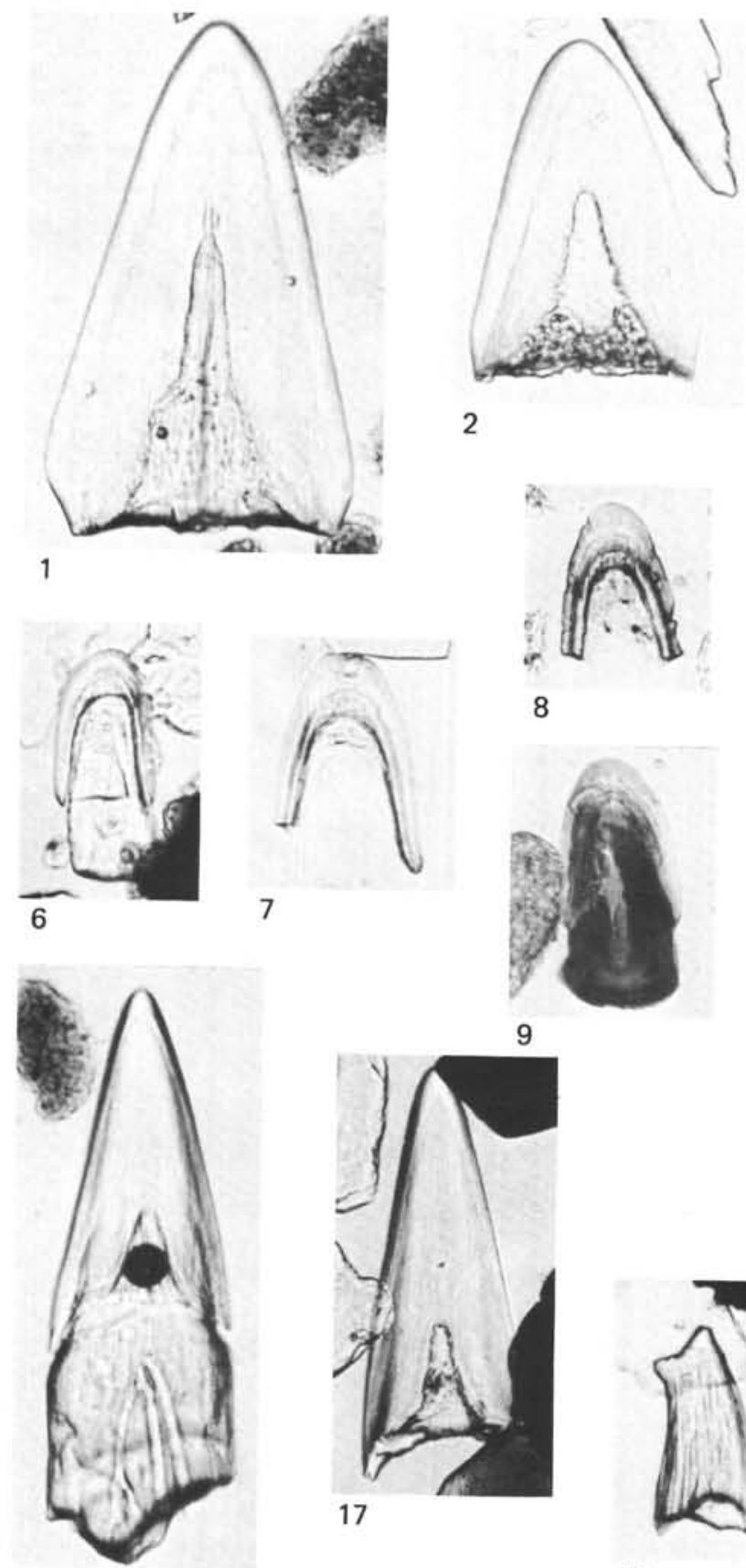

16

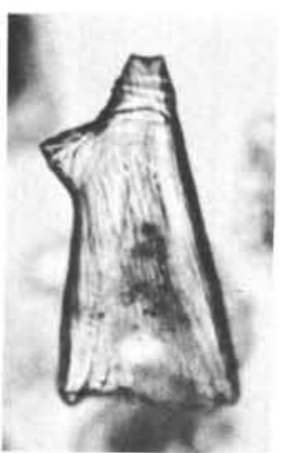

22

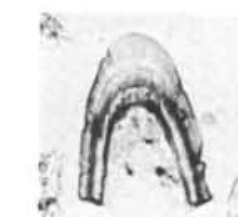

8
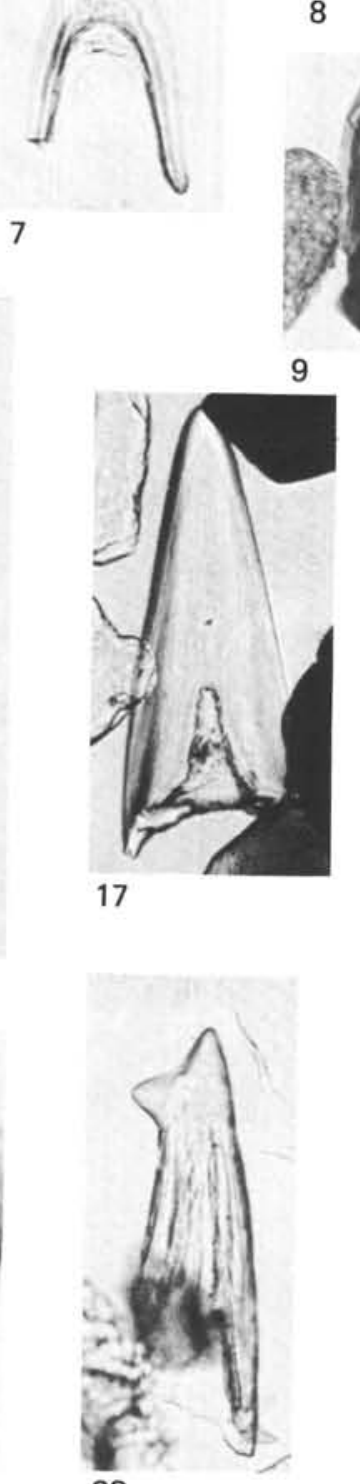
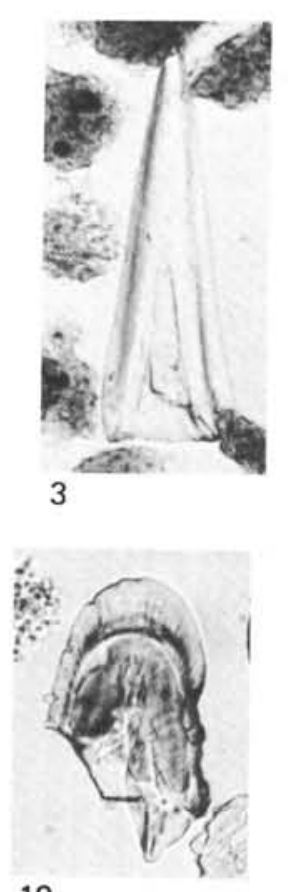

10

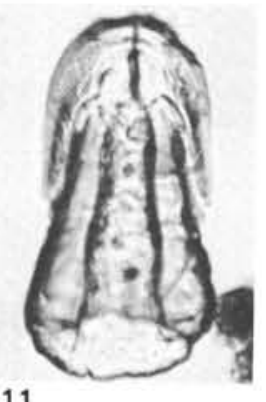

11

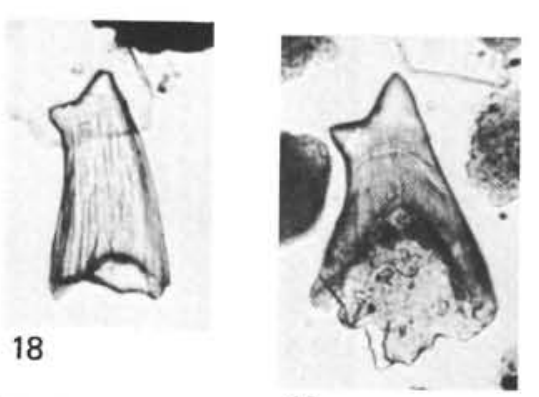

19

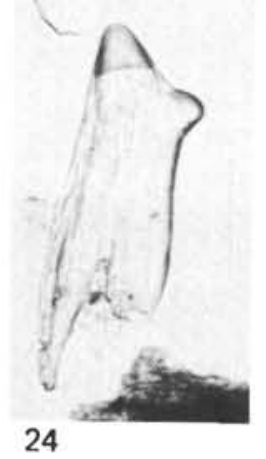

25

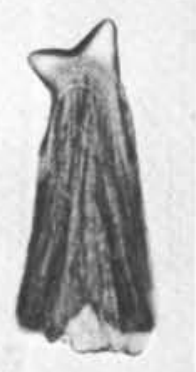

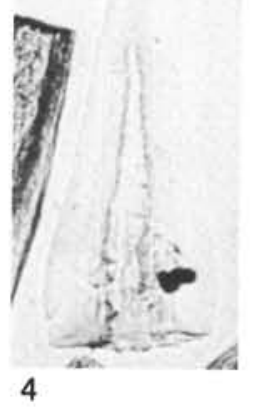
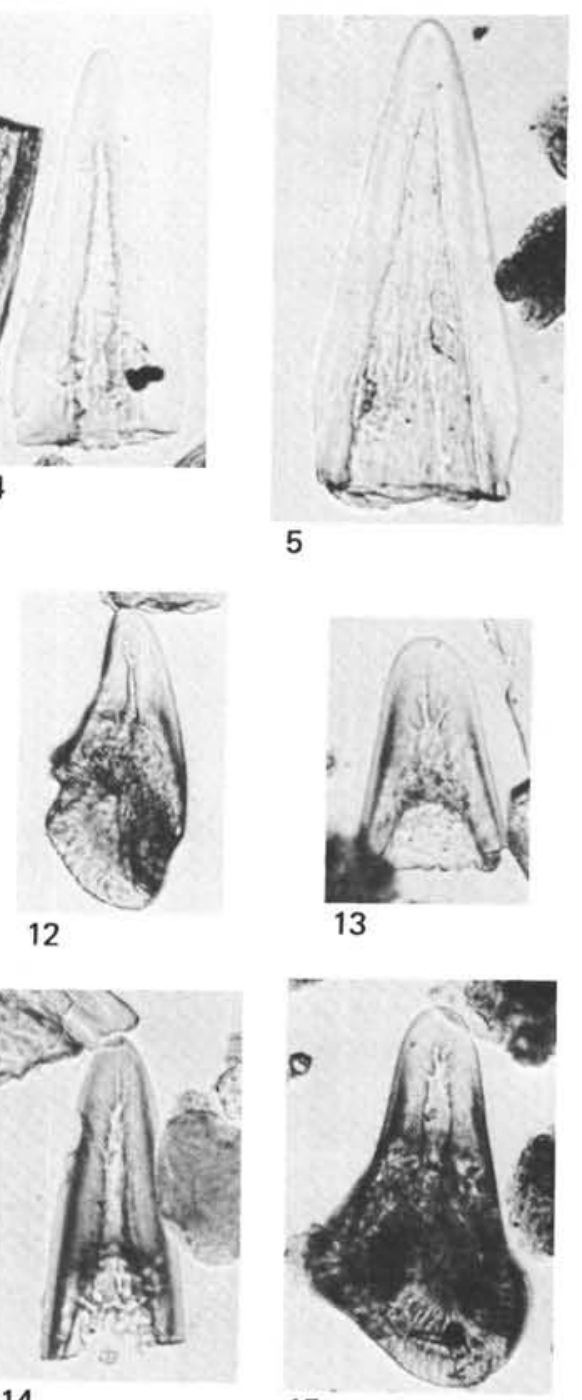

15

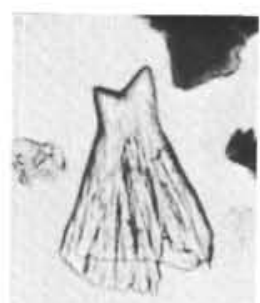

20

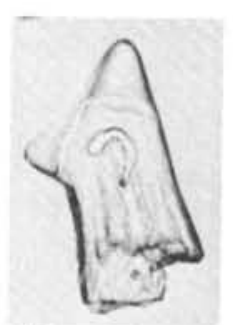

21

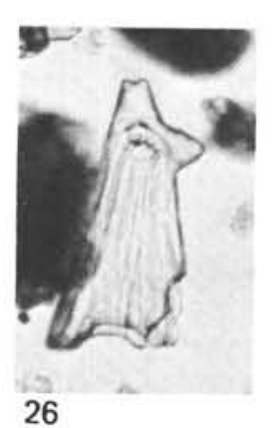

27 


\section{PLATE 4}

All figures are magnified $165 \times$, unless otherwise specified.

Figures 1-4 $a 9 / b 6 / c 2-5 / d 2 / e l$.

Triangular toothed.

1. 361-14-2, 19-24 cm, Sl.4, S19.

2. 361-12-2, 22-28 cm, Sl.1, R32/3.

3. $361-12-5,84-90 \mathrm{~cm}, \mathrm{Sl} .5$, U19.

4. $361-12-3,21-27 \mathrm{~cm}, \mathrm{Sl} .3, \mathrm{~N} 15 / 2$.

Figures 5-18 Undescribed forms.

5. 361-10-2, 92-95 cm, Sl.3, M29.

6. $361-11-3,16-21 \mathrm{~cm}, \mathrm{Sl} .3, \mathrm{~V} 6 ; 106 \times$. There are many of these forms present in Cores 11-13.

7. 361-12-3, 21-27 cm, Si.2, D15; 106×. A form similar to Ramsey et al., in press, pl. 4, fig. 10 from a late Cretaceous sample.

8. 361-12-2, 22-28 cm, Sl.1, L5/2; 106×.

9. $361-10-6,29-36 \mathrm{~cm}, \mathrm{Sl} .4, \mathrm{M} 38 / 3$.

10. 361-9-6, 132-138 cm, Sl.3, Q33; 106X.

11. $361-12-2,22-28 \mathrm{~cm}$, Sl.1, L31/1; 106×. Broken fragments present in Cores 9-12.

12. $361-11-2,16-21 \mathrm{~cm}, \mathrm{Sl} .1, \mathrm{~V} 25$.

13. 361-12-2, 22-28 cm, Sl.1, V19/3; 106×.

14. $361-14-2,19-24 \mathrm{~cm}, \mathrm{Sl} .4, \mathrm{C} 34 / 2 ; 106 \times$. Three of these forms appear in this sample.

15. 361-10-6, 29-36 cm, Sl.1, S24; 67.5X.

16. Same sample, Sl.2, T21; $67.5 \times$.

17. Same sample, $\mathrm{S} 1.2, \mathrm{~S} 33 / 3 ; 67.5 \times$.

18. 361-9-2, 128-132 cm, Si.7, N10/2; 106X. Similar forms present in Cores 9 and 10, Section 2. 

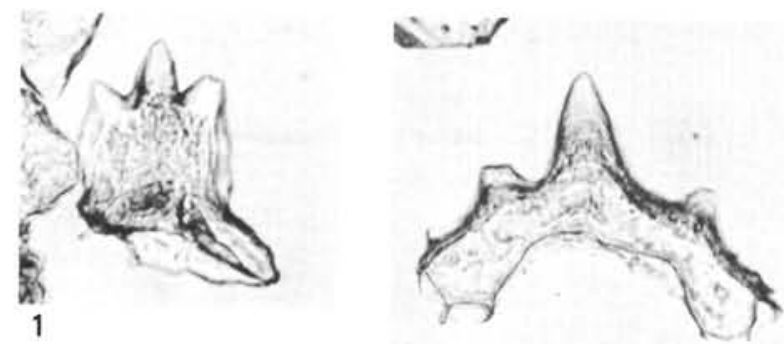

PLATE 4
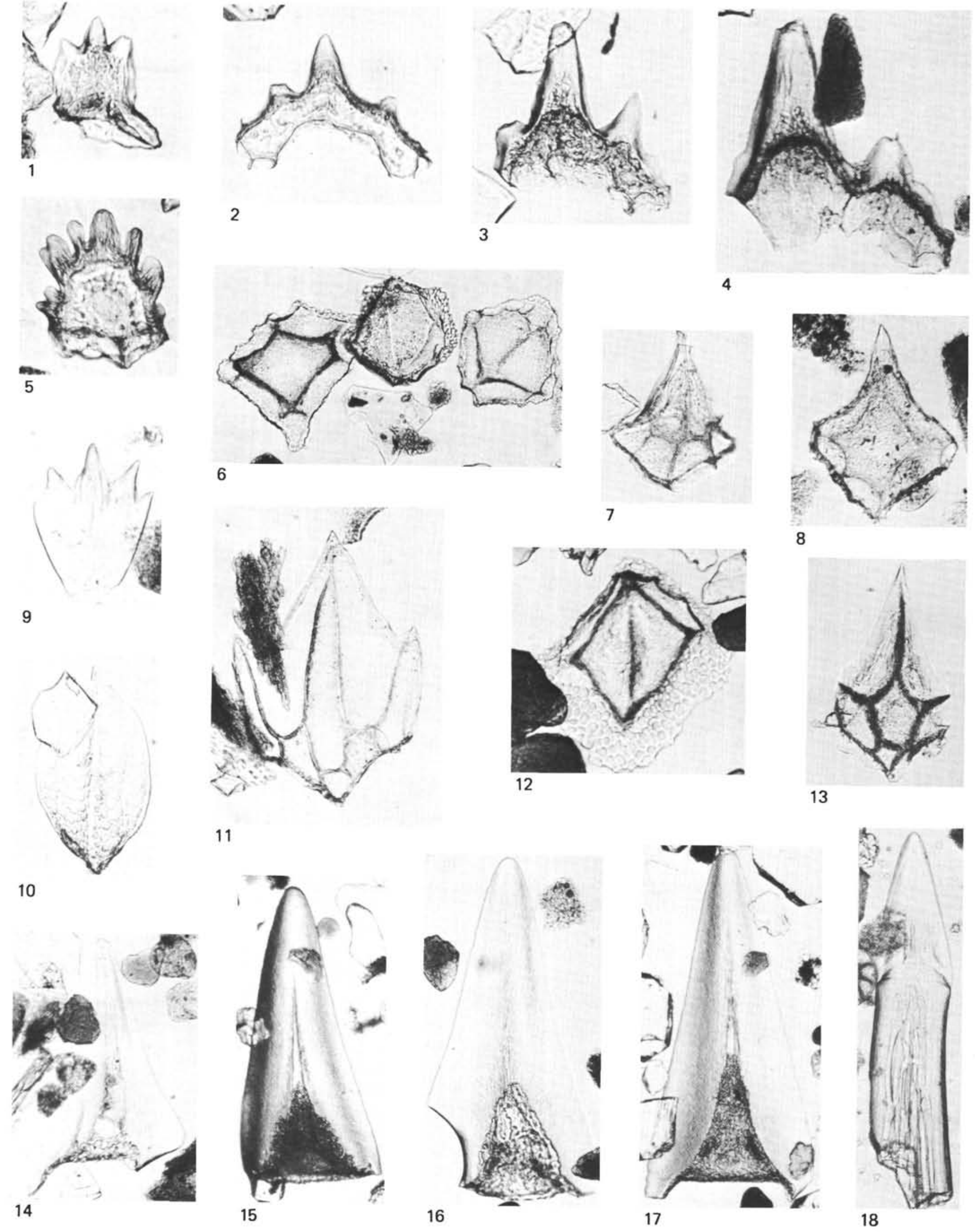